Nova Southeastern University

Florida

NSUWorks

NOVA SOUTHEASTERN

UNIVERSITY

Faculty Scholarship

Shepard Broad College of Law

Winter 1-1-2015

\title{
The Codification of Professionalism: Can you Sanction Lawyers into Being Nice?
}

Debra M. Curtis

Nova Southeastern University - Shepard Broad College of Law

Follow this and additional works at: https://nsuworks.nova.edu/law_facarticles

Part of the Legal Ethics and Professional Responsibility Commons, and the Legal Profession Commons

\section{NSUWorks Citation}

Debra M. Curtis, The Codification of Professionalism: Can you Sanction Lawyers into Being Nice?, $40 \mathrm{~J}$. Legal Profession 49 (2015),

Available at: https://nsuworks.nova.edu/law_facarticles/420

This Article is brought to you for free and open access by the Shepard Broad College of Law at NSUWorks. It has been accepted for inclusion in Faculty Scholarship by an authorized administrator of NSUWorks. For more information, please contact nsuworks@nova.edu. 


\section{The Codification of Professionalism: Can you Sanction Lawyers into Being Nice? By Debra Moss Curtis ${ }^{1}$}

\section{Introduction}

On October 31, 2013, the Florida Supreme Court in The Florida Bar v. Norkin made it clear that "it wants the trend of escalating incivility among lawyers to stop." ${ }^{2}$ With that decision, in which a lawyer was suspended and publicly reprimanded for his behavior, the court urged that "Members of the Florida Bar, law professors, and law students should study" this case "as a glaring example of unprofessional behavior." ${ }^{3}$ This article heeds the courts' directive to do so, but also place it in the context of the movement to enhance professionalism statewide.

At the heart of the professionalism movement is a conflict—between the idea that professionalism is an aspirational goal of behavior and that it is one that can be legislated with penalties. When professionalism standards are aspirational, professionalism codes are not a basis of judicially imposed conduct. ${ }^{4}$ In contrast, ethical rules governing attorneys do carry sanctioning behavior in an attorney discipline system. ${ }^{5}$ Confusion can often lie in the fact that there are some aspects of poor professional behavior that cross over into conduct violations of the discipline system and thus are the subject of sanctioning cases. ${ }^{6}$ That intersection of behavior, aspirations and rule violations are the focus of this examination into professionalism.

The discussion about the legal profession and its members' behavior associated with unprofessionalism isn't new. While the talk about the problem may have reached a fever pitch in

\footnotetext{
${ }^{1}$ Debra Moss Curtis is a Professor of Law at the Nova Southeastern University Shepard Broad College of Law, teaching Contracts and UCC courses. She is the Chair of the Legal Education Group of Vision 2016, the Florida Bar's Commission looking at the Future of the Profession. Special thanks to NSU Law students and graduates Mary Grecz, Bridget O. Asekunowo, Shanttel Grullon and Hayley Newman.

${ }^{2}$ Samson Habte, Lawyer's Appalling Incivility Warrants Tougher Sanction Than What Bar Sought, ABA/BNH Lawyers Manual on Professional Conduct, Nov. 20, 2013.

${ }^{3}$ The Florida Bar v. Norkin, 132 So.3d 77 (Fla. 2013).

${ }^{4}$ American Civil Trial Bar Roundtable White Paper on Increasing the Professionalism of American Lawyers at 12. http://www.americanbar.org/content/dam/aba/administrative/house_of_delegates/resolutions/2014_hod_annual_mee ting_105b.authcheckdam.pdf (last visited August 12, 2015).

5 The Florida Bar, www.flabar.org (last visited August 12, 2015)

${ }^{6}$ American Civil Trial Bar Roundtable White Paper supra note 4 at 13.
} 
some states recently, it is a topic talked about for years ${ }^{7}$. The ABA concluded nearly thirty years ago that "lawyers' professionalism may well be in steep decline." 8 Nearly 20 years ago, scholars wrote of a tri-parte crisis of professionalism — an increase in lawyer unprofessional behavior, the public opinion of lawyers dropping greatly, and lawyer dissatisfaction with careers-all rose. ${ }^{9}$ Anecdotal stories date the problems back further. As most people know, there is an entire genre of jokes regarding attorney behavior, likening them to "sharks," "bottom dwellers" and the like, and while they may stem from a variety of reasons, it is clear some of that reputation has to do with lawyers being perceived as being less than nice. ${ }^{10} \mathrm{In}$ a recent Gallup poll, lawyers fell toward the bottom of a ranked list rating honesty and ethical professional behavior -only twenty percent rated lawyers high/very high. ${ }^{11}$

So the question is why isn't more done to crack down on unprofessional behavior of lawyers? Part of the problem of governing professionalism, it has been asserted, has been a lack of a specific definition of "what is professionalism"-and the suggestion that the concept is too broad to define and thus enforce. ${ }^{12}$ Other challenges to governing it have been the reinforcement of the idea that professionalism is only a concept that exists in an aspirational nature. ${ }^{13}$ However, there is currently a movement to provide more substantial definitions close the gap between professionalism being seen as "merely" aspirational to becoming actually enforceable ${ }^{14}$

\footnotetext{
${ }^{7}$ See generally Don J. Young \& Louise L. Hill, Professionalism: The Necessity for Internal Control, 61 TEMP. L. REV. 205, 205 (1988)

${ }^{8}$ Keith W. Rizzardi, Defining Professionalism: I know It When I See It? 79 Fla. B.J 38 (July/August 2005).

${ }^{9}$ Susan Daicoff, Lawyer, Know Thyself: A Review of Empirical Research on Attorney Attributes Bearing on Professionalism, 46 AM. U. L. REV. 1337, 1340 (June 1997).

${ }^{10}$ E.g. Lawyer Jokes and Cartoons, http://www.lawyer-jokes.us/ (last visited June 30, 2015)

${ }^{11}$ Honesty/Ethics in Professions, GALLUP.COM, http://www.gallup.com/poll/1654/honesty-ethicsprofessions.aspx. (last visited June 30, 2015).

${ }^{12}$ Rizzardi, supra note 7.

${ }^{13}$ Id.

${ }^{14} I d$.
} 
In recent years, the Florida Bar has moved to stating that "professionalism is expected" and not aspirational. ${ }^{15}$ This shift has been evidenced by revisions of oaths, a proliferation of information disseminated, recent discipline cases, a Supreme Court order establishing local professionalism regulation, and other actions, all of which will be discussed in this article. ${ }^{16}$ The $\mathrm{ABA}$ also continues to be a part of the conversation through its Standing Committee on Professionalism and the extensive outreach they perform. ${ }^{17}$ Judges also are speaking out more. ${ }^{18}$ In several cases in Florida in recent years, judges have noted that "improper comments on the credibility of opposing counsel are occurring too often and that attorneys need to uphold professional and ethical obligations while practicing" as well as criticizing professionalism of attorneys. ${ }^{19}$ Clearly, there exists an emerging and converging message about the importance of professionalism from all aspects of the Bench and Bar.

This article examines the status of governing professionalism in Florida. Part II of this article discusses general efforts to define professionalism. Part III gives a brief summary of the attorney discipline system, followed by a review of how some recent cases shaped the Florida Supreme Court's message on professionalism. Part IV of this article will discuss the broader approach in Florida of dealing with professionalism, as ordered by the Florida Supreme court statewide, including data and details about the new Local Professionalism Panels, and whether these efforts have been and can be successful. Part V suggests what more can be done and draws

${ }^{15}$ Center for Professionalism, FLABAR.ORG, http://www.floridabar.org/professionalism (last visited July 22, 2015). ${ }^{16} \mathrm{Id}$.

${ }^{17}$ Standing Committee on Professionalism, AMERICANBAR.ORG, http://www.americanbar.org/groups/professional_responsibility/committees_commissions/standingcommitteeonprof essionalism2.html (last visited July 22, 2015)

${ }^{18}$ Civility Counts - Judge Meenu Sasser, Cir. Courier, News Bulletin of the Fifteenth Judicial Circuit, 2014-1, Jan.March 2014, at 5, available at http://15thcircuit.co.palm-

beach.fl.us/documents/10179/19429/newsletter_JanMarch2014.pdf?version=1.0\&t=1399918849000 (last visited July 22, 2015).

${ }^{19}$ Kevin Joyce, Wining Is Not Always Winning, The Professional, A Publication of the Henry Latimer Center for Professionalism, Volume XI, No. 6, Winter 2013 at 6. 
some conclusions on the nexus between governing professionalism and attorney discipline as we move forward.

\section{What is Professionalism?}

There is no one definition that is universally accepted on what attorney "professionalism" encapsulates. ${ }^{20}$ The term "encompasses the standards, values and qualities of members of a profession." ${ }^{21}$ It has been extensively discussed in a variety of resources, including those influencing legal education, such as Best Practices for Legal Education and the now iconic Carnegie Report, as well as countless Bar publications and law journals, but there is no one agreed upon set of standards that form the parameters of professional behavior. ${ }^{22}$

Miriam Webster defines "professionalism" as "the skill, good judgment, and polite behavior that is expected from a person who is trained to do a job well." ${ }^{23}$ Using this definition, we can break it down into several parts - that someone who is acting in a professional manner is skilled, has good judgment regarding interactions with people and their work, and is acting in accordance with a socially constructed set of norms that would generally be considered "polite." The definition also notes that this behavior is expected when someone has good training in their job. $^{24}$

If we wanted to import this simple definition into the legal profession, and consider the well documented crisis of professionalism in the field - it leads to questions of what might be causing a professionalism crisis. Is it: 1 . Attorneys are not trained well. 2 . They are not acting politely even if they are. 3. They are exercising bad judgment. 4. They are not skilled or not

${ }^{20}$ Paula Schaefer, A Primer on Professionalism for Doctrinal Professors, 81 TENN. L. REv. 277, 279 (2013-2014).

${ }^{21} I d$.

${ }^{22}$ Id. at 280.

${ }^{23}$ Miriam-Webster Dictionary, Professionalism, http://www.merriam-webster.com/dictionary/professionalism (last visited July 22, 2015).

${ }^{24} I d$. 
demonstrating those skills. Or is it a combination of these things? Or is it that professionalism is really something else?

Some discussions of professionalism use the words "civility" "honesty" "integrity" and "character" to describe this concept. ${ }^{25}$ These more specific words represent an attempt to pin down detailed traits of the general concept of professionalism so as to be able to incorporate them into teaching and training lawyers. ${ }^{26}$

Other approaches to defining professionalism have combined ideals of professionalism with existing rules and regulations governing the profession. One scholar has suggested three aspects of professionalism by attorneys:

1. They fulfill duties to clients

2. They comply with professional conduct rules

3. They exhibit core personal values essential to being a good lawyer. ${ }^{27}$

Such a definition brings in both the concept of personal values that most general definitions reference, as well as a reminder that the profession is not just governed by an aspirational code, but an enforceable one. Another such scholar has suggested that an amalgamation of already existing resources could help provide a ready definition of professionalism—-pulling from the Bar's rules of professional conduct, the ideals of goals of professionalism, the guidelines for professional conduct, CLE requirements for Professionalism, the Oath of Admission to the Florida Bar, and the Bar's Creed of Professionalism. ${ }^{28}$

The combination of these definitions and the differences among them is at the heart of the controversy explored in this article. A look at them brings the realization that failure by an

\footnotetext{
${ }^{25}$ Schaefer, supra note 19 , at 280.

${ }^{26} I d$. at 281 .

${ }^{27} I d$. at 282 .

${ }^{28}$ Rizzardi, supra note 7.
} 
attorney to meet some of these suggested definitions of professionalism are already actual disciplinary offenses as described by the Rules Regulating the Florida Bar. ${ }^{29}$ Numerous examples of how failure to properly represent a client or accurately maintain a trust account have led to various sanctions under these rules are available throughout many years. ${ }^{30}$ However, failure to live up to other aspects of the definition, such as "exhibiting core personal values" or "civility," are not necessarily sanctionable, triggering the debate regarding the ability to govern professionalism-should they all be considered similar problems of the profession?

Many of these definitions require even deeper examination. What are some of these aspects of professionalism? What are "core personal values" or 'polite behavior" or "character"? Some definitions are available — such as core personal values, which has been discussed as those necessary to be "effective in relationships" with and in the "treatment of others," as someone who accepts a special role in the legal system and society, demonstrates a strong work ethic and works effectively with others, and continuously strives for personal growth and fulfillment." 31 But even with more specific definitions, can you really govern these traits through a discipline system, or are they simply too personal? And if you can be specific about some aspects of being professional but more general in others, can you enforce professionalism throughout a population of diverse individuals practicing in it?

One scholar, in noting that there is a difference between a career, in which you pass your time in an occupation, and a "professional" which comes from the Latin root "for a vow or a declaration of belief that you make" has opened the door to considering the motivation and roots

\footnotetext{
${ }^{29}$ See R. Regulating Fla. Bar, available at www.flabar.org. (last visited August 12, 2015).

${ }^{30}$ See e.g. Disciplinary Actions, The Florida Bar News, https://www.floridabar.org/DIVCOM/JN/JNnews01.nsf/Articles/F56FA5DBE723ADE985257BFD0047C5D2 (last visited August 12, 2015).

${ }^{31}$ Schaefer, supra note 19, at 277.
} 
of being a professional. ${ }^{32}$ If so, then the obligation of being a lawyer as a professional is personal - and our professional identity as lawyers is "at the center of our professional morality." ${ }^{33}$ Given that premise, professionalism and professional obligation to our codes and clients should be part of professional responsibility as enforced by codes because it is inseparable from the work we do and who we are as lawyers.

Furthermore, we must look at deep theory of professionalism to see what our motivation is for following rules to see if they can be enforced through a discipline system. Motivations are "goal" based, "rights" based, or "duty" based. ${ }^{34}$ If your motivation is goal based, you follow a rule because it promotes your goal — usually related to a political or economic theory, for a specific end result desired. ${ }^{35}$ For example, as a lawyer, a goal based motivation for professionalism may be that you follow the rules because if you don't, you may lose your license and therefore not be able to support yourself in your lifestyle. ${ }^{36}$ This is a very clear and internal system of motivation, and one that makes for an easier tie-in to governing behavior by a disciplinary system. By contrast, "rights" based theory of motivation is one based on human freedom - the motivation that you follow rules because they define the parameters of personal freedom — and although notable, these are not particularly helpful in day to day decision making as to actions for most people. ${ }^{37}$ The last theory is "duty based"-founded in classical and religious traditions, which may not have an immediate short term reward, but have larger, longer term motivations of the spirit and mind. ${ }^{38}$ Again, in working through the problem of professionalism in attorneys, these last two paradigms - if they are the motivation for attorney

\footnotetext{
${ }^{32}$ Daniel R. Coquillete, Professionalism: The Deep Theory, 72 N.C. L. Rev. 1271(1994).

${ }^{33} \mathrm{Id}$.

${ }^{34} I d$.

${ }^{35} I d$.

${ }^{36} I d$.

${ }^{37}$ Coquillete, supra note 31.

${ }^{38}$ Id.
} 
behavior — do not seem to call for a discipline system for governing professional behavior, as attorneys' behavior is not motivated by anything related to the discipline system and thus not helpful to enforcement. ${ }^{39}$ These deep rooted questions remind us of the many difficulties in defining and understanding professional behavior and wanting to control it.

But just because governing professionalism is difficult, it cannot be ignored.

Professionalism is not only considered by some as the heart of the profession, but the key to the survival of the legal profession in these changing times. ${ }^{40}$ For some, the essence of this notion is that ethical rules are the floor of acceptable conduct under which attorney discipline is risked. But merely abiding by these bottom-line rules does not guarantee or even encourage professional behavior. As discussed and debated, professional behavior in its true form includes a whole range of behavior not explicitly required in the rules, such as service and collegiality, and the essence of how lawyers interact with others in their work. ${ }^{41}$ How do these get enforced?

There is a difference between ethical rules and professional concepts relating to lawyers. According to one view, "ethical rules delineate the way lawyers must behave; professionalism concepts animate the way lawyers should behave and practice. ${ }^{\circ 2}$ Interestingly, this perspective leads to two possible viewpoints on disciplining for professionalism. One comes from the first part of that perspective - that ethics are the floor. Using a building analogy, if ethics are the floor or foundation, then professionalism is built on top of them, necessarily incorporating them into the whole of professionalism, and violations of professionalism are a violation of the whole, thus requiring discipline as well. On the flip side, if professionalism traits are seen extraneous to ethical violations - a separate entity merely resting on top of the foundation, then in this analogy,

${ }^{39} I d$.

${ }^{40}$ Professionalism as Survival Strategy, Your ABA June 2015, http://www.americanbar.org/publications/youraba/2015/june-2015/building-a-practice-through-professionalism.html (last visited May 28, 2015).

${ }^{41} I d$.

${ }^{42} I d$. 
there can be cracks above ground without compromising the foundation - a viewpoint that only violations of those core floor traits are within the discipline range. This struggle - to define professionalism, and see if it has a place in the existing ethical rules systems--is at the heart of the debate on governing professionalism.

\section{Developing Professionalism Theory in Florida-Attorney Discipline versus Professionalism Codes and Cases}

\section{A. The Attorney Discipline System and the Rules Regulating the Florida Bar}

Unlike other professions in Florida that are subject to central government regulation such as the Department of Business and Regulation, attorneys have the privilege of a self-regulation and discipline system through the Florida Bar and the Florida Supreme Court. ${ }^{43}$ In short, the process has been described as having six stages. ${ }^{44}$ The first stage is the intake of a complaint against an attorney, which may come from a wide variety of sources including clients, other attorneys, judges, or the Bar's own discovery of misconduct. ${ }^{45}$ Through the intake process, conducted by the Attorney Consumer Assistance Program (ACAP), the Bar will determine whether the allegations warrant discipline under the Rules Regulating the Florida Bar. ${ }^{46}$ If no discipline is warranted, the case is closed, but if the facts as alleged would constitute a violation of the rules warranting discipline, a file is opened, and a notification and response process is begun. ${ }^{47}$ After this basic process, the file may be closed if no facts support a violation warranting

\footnotetext{
${ }^{43}$ See, Judicial Regulation of Lawyers, The Florida Bar News, http://www.floridabar.org/DIVCOM/PI/BIPS2001.nsf/1119bd38ae090a748525676f0053b606/8c1e74a1b6ef2ab385 25669e004cd0f9! OpenDocument (last visited August 12, 2015.)

${ }^{44}$ Brian D. Burgoon, The Bar's Procedure for Investigating and Prosecuting Disciplinary Complaints, The Florida Bar News, February 1, 2014 available at www.flabar.org (last visited July 22, 2015).

${ }^{45} I d$.

${ }^{46} I d$.

${ }^{47} I d$.
} 
discipline, or the case will be forwarded to one of the five branch offices of the bar that is assigned to handle the judicial circuit where the attorney practices. ${ }^{48}$

After assignment to bar counsel in stage two, the case could be closed if further analysis reveals that discipline is not appropriate, or the case may be recommended for non-discipline diversion to a practice and professionalism enhancement program where appropriate. ${ }^{49}$ However, if it is determined that there are sufficient grounds for possible discipline, the complaint is forwarded to the third stage, to be prosecuted by the Bar and heard by a grievance committee in the accused lawyer's judicial circuit. ${ }^{50}$

These grievance committees, comprised of both lawyer and public members, function like a grand jury to complete further investigation and a determination of whether there is probable cause of a Rule violation warranting disciplinary action. ${ }^{51}$ The committee can make one of a variety of findings on the case from this point. If they find no probable cause, the case is concluded with no discipline imposed. ${ }^{52}$ Otherwise, they could find minor misconduct which includes an admonishment, recommend diversion, defer the case pending the conclusion of another matter against the accused or find probable cause, which would send the case to the fourth stage, trial. ${ }^{53}$

If a case gets to the trial stage, a formal complaint is filed with the Florida Supreme Court by Bar Counsel. ${ }^{54}$ A circuit or county court judge in the respondent's circuit is then appointed to serve as the Referee for the case. ${ }^{55}$ If not disposed of pretrial, the Referee then conducts a trial of the case, which includes hearing witnesses and receiving evidence, and issuing a report

\footnotetext{
${ }^{48} \mathrm{Id}$.

${ }^{49}$ Burgoon, supra note 43.

${ }^{50} \mathrm{Id}$.

${ }^{51} I d$.

${ }^{52} I d$.

${ }^{53} I d$.

${ }^{54} I d$.

${ }^{55} I d$.
} 
containing factual and legal findings, a recommendation of guilt or innocence and a recommendation of the sanctions that are appropriate for the rule violation. ${ }^{56}$

These recommendations are then sent to the Supreme Court for approval, and are not final until that happens. The report is also reviewed by the Board of Governors in the fifth stage, allowing for an appeal of the Referee's decision by the Board or the Respondent. ${ }^{57}$ The Board of Governors has a detailed process for review including a Disciplinary Review Committee that makes recommendations to the Board of Governors. ${ }^{58}$ The Board can review grievance committee decisions, consent judgments, disbarments on consent, disciplinary revocations, and reports of Referees, disagreeing with any aspects, and can seek review by the Supreme Court of Referee's decisions, the sixth and final stage. ${ }^{59}$

The Florida Supreme Court's powers of review include that to approve or disapprove the report of the Referee in total, including any findings, and to order a discipline different than what was recommended through the process. ${ }^{60}$ As the Florida Supreme Court is the "ultimate and final authority on lawyer discipline matters," their order is final. ${ }^{61}$

Findings of misconduct and recommended sanctions are rooted in the Rules Regulating the Florida Bar, which both describe the parameters of attorney misconduct and the possible sanctions for having violated such rules. ${ }^{62}$ The Rules themselves are actually in twenty chapters and go far beyond attorney conduct and discipline. ${ }^{63}$ Chapter 4 governs the rules of attorney professional conduct, and includes directives on a wide variety of behaviors within the profession, including the client-lawyer relationship in its entirety (Rules in section 4.1), duties as

\footnotetext{
${ }^{56} \mathrm{Id}$.

${ }^{57} \mathrm{Id}$.

${ }^{58} I d$.

${ }^{59} I d$.

${ }^{60} I d$.

${ }^{61} I d$.

${ }^{62}$ R. Regulating Fla. Bar, available at www.flabar.org (last visited July 30, 2015).

${ }^{63} \mathrm{Id}$.
} 
a counselor (Rules 4.2), duties as an advocate (Rules 4.3), duties in transactions with persons other than clients (Rules 4.4), rules governing law firms associations (Rules 4.5), rules regarding public service (Rules 4.6), rules regarding information about legal services (advertising) (Rules 4.7), and rules governing the maintenance of the integrity of the profession (Rules 4.8). ${ }^{64}$

Much of the behavior considered unprofessional which spurs discipline in Florida case law are actually findings of violations of various parts of Rule 4 regulating the Florida Bar and its many parts dealing with attorney behavior in their work. Once those violations are found Rule 3 of the Rules Regulating the Florida Bar lays out the discipline process and the resulting ramifications of them. ${ }^{65}$ After a finding of misconduct, the Florida Supreme Court considers various factors when determining the appropriate sanction, such as the duty violated; the lawyer's mental state; the potential or actual injury caused by the lawyer's misconduct; and the existence of aggravating or mitigating factors. ${ }^{66}$ Such sanctions can include disbarment, suspension, emergency suspension, public reprimand, admonishment, and probation. ${ }^{67}$

\section{B. Recent Florida Case Law Disciplining Attorneys on Behavior}

As the ultimate governing body, the Florida Supreme Court has issued many opinions discussing discipline, and there have been a recent number dealing with behavior that is unprofessional and that resulted in attorneys receiving discipline. A snapshot look at the past twenty years shows an increasing focus on the Court discussing attorneys' unprofessional behavior in finding violations of the Rules Regulating the Florida Bar warranting discipline.

Nearly twenty years ago, the court issued opinions highlighting problems of professionalism. While the court was clear in each case as to which Rules Regulating the Florida

\footnotetext{
${ }^{64} I d$.

${ }^{65} \mathrm{Id}$.

${ }^{66}$ Debra Moss Curtis, Attorney Discipline Nationwide, 35 J. LegAL Prof. 209, 235 (2011).

${ }^{67} \mathrm{Id}$.
} 
Bar were violated thus warranting discipline, the attorney's unprofessional behavior was a clear part of the problem discussed. In a 1996 case, The Florida Bar v. Wasserman, an attorney was suspended for six months after his behavior at a hearing included shouting, waving his arms and challenging a judge to hold him in contempt after a ruling. ${ }^{68}$

In 1997, in The Florida Bar v. Martocci, the court called an attorney "patently unprofessional" for poking another attorney in the chest and using unacceptable language. ${ }^{69}$ While not suspended for this poking incident, this same attorney called another attorney a "nut case" and "crazy" in another case in 2001, and earned a public reprimand and two years' probation. ${ }^{70}$ In that 2001 case, Martocci made demeaning facial gestures and stuck out his tongue at depositions, called the opposing counsel a "stupid idiot" and "b-tch" and that "she should go back to Puerto Rico", for which he was found guilty of violation of rule 4-8.4(d), which reads that a lawyer shall not "(d) engage in conduct in connection with the practice of law that is prejudicial to the administration of justice, including to knowingly, or through callous indifference, disparage, humiliate, or discriminate against litigants, jurors, witnesses, court personnel, or other lawyers on any basis, including, but not limited to, on account of race, ethnicity, gender, religion, national origin, disability, marital status, sexual orientation, age, socioeconomic status, employment, or physical characteristic." 71

In his defense in that later case, Martocci argued his previous failure to be disciplined for similar actions was reason why he should not be disciplined here-- explicitly raising the

\footnotetext{
${ }^{68}$ Kevin Joyce, A Trip Down Professional Lane, The Professional, A Publication of the Henry Latimer Center for Professionalism Volume XI, No 7 Spring 2014 at 3.

${ }^{69} I d$.

${ }^{70} \mathrm{Id}$.

${ }^{71}$ Florida Bar v. Martocci, 791 So.2d 1074 (Fla. 2001).
} 
intersection between professionalism behavior and that warranting discipline. ${ }^{72}$ The court noted that:

Martocci's second claim is that, even if the Referee's findings of fact are correct, Martocci's conduct was not prejudicial to the administration of justice as it did not rise to a level that violated rule 4-8.4(d). In support of this proposition, Martocci argues that Florida Bar v. Martocci, 699 So.2d 1357 (Fla.1997), established a distinction between unprofessional conduct and unethical conduct violating rule 4-8.4(d). In that case, we upheld the Referee's conclusion that the Bar did not clearly and convincingly prove that Martocci violated rules 4-8.4(c) and (d), although Martocci used profanity against the opposing attorney and threatened the court reporter. However, we find Martocci to be distinguishable from the case before us today.

The court held that the later misconduct clearly prejudiced the administration of justice by further exacerbating relationships between respondent, opposing counsel, and the various judges involved in the already difficult underlying cases. ${ }^{73}$ The court noted that it had already called upon members of the Bar to refrain from offensive conduct, and that Martocci's disrespectful and abusive comments crossed the line from that of zealous advocacy to unethical misconduct. ${ }^{74}$ Additionally, as a matter of review in Martocci's first case, the court reasoned that there was competent, substantial evidence to support the Referee's resolution of the debatable issues in respondent's favor of not finding discipline. ${ }^{75}$ Similarly, the court concluded in the latter case that there was also competent, substantial evidence supporting the Referee's conclusion of guilt and therefore neither time substituted their judgement for that of the Referee. ${ }^{76}$ As noted,

\footnotetext{
${ }^{72} I d$.

${ }^{73} \mathrm{Id}$.

${ }^{74}$ See Martocci, 699 So.2d at 1360; Florida Bar v. Buckle, 771 So.2d 1131, 1133 (Fla.2000) ("a lawyer's obligation of zealous representation should not and cannot 1078 be transformed into a vehicle intent upon harassment and intimidation."). See Florida Bar v. Wasserman, 675 So.2d 103 (Fla. 1996) (attorney was disciplined under rule 4 8.4(a), violating Rules of Professional Conduct, for swearing at a judicial assistant over telephone after receiving unfavorable response to question posed to judge presiding over his case); Florida Bar v. Uhrig, 666 So.2d 887 (Fla.1996) (attorney violated rule 4-8.4(d) by mailing insulting letter to opposing party who was a member of a minority group).

75 See Martocci, 699 So.2d at 1360.

${ }^{76}$.Martocci, supra note 70 at 1074.
} 
the court here both explicitly acknowledged the difference between professionalism concerns and ethical rule violations and respected the Referee's findings in each instance as to which side of the line the behavior belonged. ${ }^{77}$

In recent years, the attention and focus on highlighting the behavior of attorneys has gotten more thorough by the court. In 2006, in The Florida Bar v. Tobkin, an attorney accused of numerous violations, among them trying to keep the opposing counsel from obtaining medical records by going to the medical center, snatching the records away from opposing counsel and screaming at the records custodian. ${ }^{78}$ The Referee found Tobkin guilty of violating Rules Regulating the Florida Bar 4-3.1 (asserting only meritorious claims and contentions), 4-3.4(a) (unlawfully obstructing another party's access to evidence), 4-3.4(c) (knowingly disobeying an obligation under the rules of a tribunal), 4-3.4(d) (making a frivolous discovery request or failing to comply with a legally proper discovery request), and 4-8.4(d) (engaging in conduct prejudicial to the administration of justice). ${ }^{79}$ In considering discipline, the Referee found one mitigating factor-absence of a prior disciplinary record-- and three aggravating factors: (1) a pattern of misconduct; (2) multiple offenses; and (3) substantial experience in the practice of law. ${ }^{80}$ The Referee recommended in this case that Tobkin be suspended for ten days, ordered to attend The Florida Bar's program on professionalism, and ordered to pay costs. ${ }^{81}$

Unlike in Martocci, The Florida Supreme court here disagreed with the Referee's recommendation, stating that Tobkin engaged in many acts of misconduct, intentionally violated court orders, filed a sham pleading, and even acted in such an unprofessional manner that

\footnotetext{
${ }^{77} I d$.

${ }^{78}$ The Florida Bar v. Tobkin, 944 So. 2d 219 (Fla. 2006).

${ }^{79} I d$.

${ }^{80} I d$.

${ }^{81} I d$.
} 
hospital security was called to deal with him. ${ }^{82}$ They held that his misconduct at the cancer center, grabbing records from people and screaming at the librarian, bordered on violent. ${ }^{83}$ Further, they noted that Tobkin continued to believe that his conduct was nothing more than zealous advocacy, and blamed his problems on the trial court, defense counsel, The Florida Bar, and the grievance committee, instead of taking responsibility. ${ }^{84}$ Based on these factors, the court discarded the recommendation of a ten-day suspension and ordered a 91 day suspension. ${ }^{85}$ This sentencing is more than merely an 81 day difference — under the Rules Regulating the Florida Bar, suspensions for 90 days or less require do not require further proof of rehabilitation, while suspensions of more than 90 days require such proof, and may require passage of all or part of the Florida Bar examination. ${ }^{86}$ While it was clear that again, the behavior, which the attorney may have considered "merely" unprofessional and not unethical, clearly fell within the range of conduct warranting discipline, the Supreme Court found a harsher view of the overall conduct, including the unprofessional aspects and was clearly sending a message about that behavior.

In 2010, in The Florida Bar v. Ratiner, Ratiner was disciplined for unprofessional conduct during a videotaped deposition.${ }^{87}$ Ratiner engaged in behavior including "forcefully" leaning over the table during a deposition, launching a tirade and tearing up an evidence sticker ${ }^{88}$ The Referee concluded that the behavior was "outrageous, disruptive and intimidating to the witness, opposing counsel and others" resulting in a public reprimand and a sixty day suspension. ${ }^{89}$ The Referee found that among others, Ratiner violated Rules Regulating the Bar 4-4.4(a) (In representing a client, a lawyer shall not use means that have no substantial purpose

\footnotetext{
${ }^{82} I d$.

${ }^{83} \mathrm{Id}$.

${ }^{84} \mathrm{Id}$.

${ }^{85} I d$.

${ }^{86}$ R. Regulating Fla. Bar, 3-5.1 (e).

${ }^{87}$ The Florida Bar v. Ratiner, 46 So. 3d 35 (Fla 2010).

${ }^{88} \mathrm{Id}$.

${ }^{89} I d$.
} 
other than to embarrass, delay, or burden a third person or knowingly use methods of obtaining evidence that violate the legal rights of such a person), 4-8.4(a) (violate or attempt to violate the Rules of Professional Conduct, knowingly assist or induce another to do so, or do so through the acts of another) and 4-8.4(d) (engage in conduct in connection with the practice of law that is prejudicial to the administration of justice, including to knowingly, or through callous indifference, disparage, humiliate, or discriminate against litigants, jurors, witnesses, court personnel, or other lawyers on any basis, including, but not limited to, on account of race, ethnicity, gender, religion, national origin, disability, marital status, sexual orientation, age, socioeconomic status, employment, or physical characteristic). ${ }^{90}$

It was suggested by the Referee with agreement by the Supreme Court that "members of the Bar and law students could view the video recording as a glaring example of how not to conduct oneself in a legal proceeding." ${ }^{\circ 1}$ It is clear that with their findings of rule violations warranting discipline, behaviors concerning professionalism are being highlighted by those involved in administering justice on these matters. If the court, in its opinion, was seeking to raise the level of conversation on the subject, it worked.

\section{The Florida Bar v. Jeffrey Norkin Case}

In July 2011, a complaint was filed against Florida attorney Jeffrey Norkin, alleging misconduct by behaving "in an unprofessional and antagonistic manner during the course of litigating a civil case." 92 The 2008 civil case in question was Gary Ferguson, individually, and

\footnotetext{
${ }^{90} \mathrm{Id}$; R. Regulating Fla. Bar available at www.flabar.org.

${ }^{91}$ Ratiner, 46 So.3d at 35.

${ }^{92}$ Norkin, 132 So.3d at 79.
} 
derivatively on behalf of Floors to Doors, Inc .v. David Beem and Floors to Doors, Inc, in which Mr. Norkin represented the Defendants, and Mr. Gary Brooks represented the plaintiffs. ${ }^{93}$

The plaintiff and defendant in this civil suit experienced serious conflict after a long term business relationship, and the defendant employed Mr. Norkin as his second attorney in the case ${ }^{94}$ According to the Supreme Court, the relationship between Mr. Norkin and Mr. Brooks as opposing council was briefly cordial but deteriorated after one month, when Mr. Norkin became "combative" and "unprofessional" not only to the opposing counsel but also to the judges involved in the matter. ${ }^{95}$ Based on his conduct, a complaint was filed in the Florida discipline system. ${ }^{96}$

Although this case has been touted in the media as being about a lawyer disciplined for "incivility" and "unprofessionalism," it is important to note the complaint and subsequent case against Mr. Norkin were tied to specific rule violations in the ethical system. ${ }^{97}$ The Referee recommended that the Supreme Court find Mr. Norkin guilty of violating four rules of the Rules Regulating the Florida Bar 4-3.5 (c), 4-8.2(a), 4-8.4 (a), and 4-8.4 (d).$^{98}$ Rule 4.3.5 is designed to cover Impartiality and Decorum of the Tribunal. Part (c) of the rule specifically states: “(c) Disruption of Tribunal. A lawyer shall not engage in conduct intended to disrupt a tribunal." 99 The comments to the rule as a whole illuminate the rule's purpose:

The advocate's function is to present evidence and argument so that the cause may be decided according to law. Refraining from abusive or obstreperous conduct is a corollary of the advocate's right to speak on behalf of litigants. A lawyer may stand firm against abuse by a judge but should avoid reciprocation; the judge's default is no justification for similar dereliction by an advocate. An advocate can present the cause, protect the record

\footnotetext{
${ }^{93} I d$.

${ }^{94} \mathrm{Id}$.

${ }^{95} \mathrm{Id}$.

${ }^{96} \mathrm{Id}$.

${ }^{97}$ See, e.g. http://www.miaminewtimes.com/news/is-jeffrey-norkin-floridas-most-obnoxious-lawyer-the-statesupreme-court-seems-to-think-so-6539318; R. Regulating Fla. Bar. available at www.flabar.org

${ }_{98}$ Norkin, 132 So. $3 d$ at 79.

${ }^{99}$ R. Regulating Fla. Bar available at www.flabar.org.
} 
for subsequent review, and preserve professional integrity by patient firmness no less effectively than by belligerence or theatrics. ${ }^{100}$

Upon hearing, the Referee found that Mr. Norkin demonstrated unprofessional behavior in front of two judges. ${ }^{101}$ The Supreme Court extensively quoted the trial record, citing examples of the judges both asking and telling Mr. Norkin repeatedly to stop yelling or raising his voice, and commenting on his rudeness. ${ }^{102}$ The Referee found that the Mr. Norkin's behavior was calculated and that his lack of "professionalism and inappropriate courtroom demeanor made it impossible for the judges to conduct hearings" ${ }^{103}$ As such, the court ultimately found that that there was clearly "antagonistic and unprofessional behavior" and thus Norkin violated Rule 4-3.5 (c). ${ }^{104}$

The second rule violated was rule 4-8.2(a) regarding maintaining the integrity of the profession. ${ }^{105}$ The rule states in part:

a) Impugning Qualifications and Integrity of Judges or Other Officers. A lawyer shall not make a statement that the lawyer knows to be false or with reckless disregard as to its truth or falsity concerning the qualifications or integrity of a judge, mediator, arbitrator, adjudicatory officer, public legal officer, juror or member of the venire, or candidate for election or appointment to judicial or legal office. $^{106}$

The purpose of this rule is to avoid the undermining of public confidence in the justice system by false statements. ${ }^{107}$ The third rule found violated was 4.8 .4 (a) which simply states that a lawyer shall not violate or attempt to violate the rules of Professional Conduct. ${ }^{108}$ This rule

\footnotetext{
${ }^{100} \mathrm{Id}$.

${ }^{101}$ Norkin, 132 So. 3d at 82.

102 Id.at 82-83.

103 Id. at 84 .

${ }^{104} \mathrm{Id}$.

${ }^{105}$ R. Regulating Fla. Bar available at www.flabar.org.

${ }^{106} \mathrm{Id}$.

${ }^{107} \mathrm{Id}$.

${ }^{108}$ Norkin, 132 So. 3d at 80.
} 
seeks to ensure that a lawyer is professionally answerable for offenses that indicate lack of those characteristics relevant to law practice. ${ }^{109}$

In this case, the Referee found that Mr. Norkin violated both these second and third rules, as according to the findings, he engaged in correspondence to a senior judge that "improperly threated the filing of a legal action" against him as well as asserting that the senior judge was involved in a conspiracy. ${ }^{110}$ Additionally, the court found that these assertions were made to third parties and for the sole purpose of dissolving a writ of garnishment against him. ${ }^{111}$ Furthermore, in efforts to get the judge presiding over the case to recuse himself, the Referee found that that Mr. Norkin also made disparaging comments regarding both this judge and another. ${ }^{112}$

The last rule that Mr. Norkin was found to violate was 4-8.4(d) which prohibits an attorney from:

(d) engag[ing] in conduct in connection with the practice of law that is prejudicial to the administration of justice, including to knowingly, or through callous indifference, disparage, humiliate, or discriminate against litigants, jurors, witnesses, court personnel, or other lawyers on any basis, including, but not limited to, on account of race, ethnicity, gender, religion, national origin, disability, marital status, sexual orientation, age, socioeconomic status, employment, or physical characteristic; ${ }^{113}$

Mr. Norkin was also found by the Referee to be guilty of violating this rule, evidenced by a string of emails to the opposing counsel, a thirty year member of the Bar without blemish to his record. ${ }^{114}$ Such emails included such insults as calling the opposing counsel incompetent, a liar, improper, and his work laughable and "scurrilous." ${ }^{.15}$ All in told there were ten email or in person communications from Mr. Norkin in which the Referee found he directly or publicly

\footnotetext{
${ }^{109}$ R. Regulating Fla. Bar available at www.flabar.org.

${ }^{110}$ Norkin, 132 So. $3 \mathrm{~d}$ at 80.

${ }^{111} I d$.

${ }^{112} I d$.

${ }^{113}$ R. Regulating Fla. Bar. 4-8.4 (d) available at www.flabar.org.

${ }^{114}$ Norkin, 132 So. $3 d$ at 79, 85 .

${ }^{115} \mathrm{Id}$. at 85 .
} 
impugned Mr. Brooks' character. ${ }^{116}$ While Mr. Norkin blamed opposing counsel for escalating the confrontation, the Referee found that Mr. Norkin's version of events that his opposing counsel "pushed him to a breaking point" were simply not credible. ${ }^{117}$

In considering the discipline to recommend, the Referee found seven aggravating factors and nine mitigating factors. ${ }^{118}$ The three aggravating factors considered most significant were Mr. Norkin's prior disciplinary offense (he was publicly reprimanded in 2003 for "disrespectful, accusatory, argumentative, and rude behavior"); a pattern of misconduct (he was previously found in civil contempt for his unprofessional behavior) and his behavior toward Bar Counsel and others during the disciplinary process itself (not straightforward nor cooperative). ${ }^{119}$ However, the Referee's consideration of the mitigating factors, including the absence of a dishonest/selfish motive, personal problem, and some interim rehabilitation, led to a recommendation by the Referee of discipline of a ninety day suspension. ${ }^{120}$

Both the Bar and Mr. Norkin challenged the Referee's recommendation of discipline. ${ }^{121}$ Mr. Norkin asserted that a public reprimand, which does not interfere with the attorney's license to practice, was at most the appropriate sanction, while in contrast, the Bar sought a one-year suspension with a public reprimand. ${ }^{122}$ Ultimately though, the Court, noting that it had a broad scope of review, actually imposed a two-year suspension and a public reprimand. ${ }^{123}$ As Courts do not second guess a Referee's recommendation without cause, and had declined to do so in several previous cases involving unprofessional behavior, this case garnered extensive discussion as to why the Court believed that the Referee's recommendation to not have a "reasonable basis

\footnotetext{
${ }^{116}$ Id. 85-86.

${ }^{117}$ Id. at 86.

${ }^{118}$ Id. at 87.

${ }^{119} \mathrm{Id}$. at $87-88$.

${ }^{120}$ Id. 88.

${ }^{121}$ Id.

${ }^{122}$ Id. at 89.

${ }^{123}$ Id.
} 
in existing case law and Florida Standards for Imposing Lawyer Sanctions" and as to why it chose a discipline far outweighing even the prosecuting bodies recommendation. ${ }^{124}$

The court began its discussion of its ordered sanction by detailing professionalism efforts by the Florida Bar and the Court during the past years, including having added additional language to the Oath of Admission to the Florida Bar, requiring new attorneys to swear, "To opposing parties and their counsel, I pledge fairness, integrity, and civility, not only in court, but also in all written and oral communications." 125 They also cited recent surveys that indicated that both lawyers and judges had significant concerns as to the effect of professionalism problems on the practice of law. ${ }^{126}$

Focusing in on Mr. Norkin's behavior, the court established a pattern of disruption, rude and antagonistic behavior, false accusations of criminal action, "relentless" unethical and unprofessional behavior in this case and in other matters. ${ }^{127}$ In establishing that this pattern of behavior violated the Rules Regulating the Florida Bar, the court relied on Florida Barv. Abramson, in which the court found another attorney guilty of violating nearly all the same rules. ${ }^{128}$ In Abramson, the Court imposed only a 91 day suspension, but here, by direct comparison found Mr. Norkin's actions far more egregious than those in the previous case. ${ }^{129}$ The Court also relied on Florida Bar v. Ratiner in which the defendant's unprofessional behavior violated the Florida rules, resulting in a sixty-day suspension, a public reprimand, and a period of probation, but contrasted that in that matter the defendant was a first time offender,

\footnotetext{
${ }^{124}$ Id. at 86 .

125 Id. at 92

${ }^{126} I d$. at 89.

${ }^{127}$ Id. at $91-92$.

${ }^{128}$ Id. at 91

${ }^{129} I d$. at 92; additionally, in dicta, the Court pointed out that if Abramson were before the court today, he would most likely receive a tougher sanction.
} 
while Mr. Norkin had a "significant disciplinary history" for the same misconduct—and stressed that the repeat nature of the offense was a significant factor. ${ }^{130}$

Mr. Norkin has maintained that he was merely aggressively, zealously representing his client. ${ }^{131}$ However, the Court noted specifically that there are ways to accomplish that without screaming, personal attacks, or humiliating opposing counsel, which they established occurred. ${ }^{132}$ As part of his sanction, Mr. Norkin was directed to appear before the Court in person for his public reprimand, noting that he was "an embarrassment to all members of the Florida Bar," in addition to his suspension from the practice of law for two years followed by an additional 18 months of probation. ${ }^{133}$

The court pointed out that "even if one considers opposing counsel to be annoying or unpleasant that does not provide a license for an attorney to engage in misconduct." ${ }^{134}$ While some have sensationalized this case as an example of a court disciplining for "mere" unprofessionalism, the court is clearly reinforcing the behavior already embodied in the Rules Regulating the Florida Bar. Attorney discipline only stems from attorney misconduct. ${ }^{135}$ Mere unpleasant or annoying conduct does not trigger the discipline process. The court here clearly and carefully analyzed the rules of conduct and established their violations in turn, some which they determined were rooted in behaviors that broke ethical rules. ${ }^{136}$ That the court also stressed the problematic unprofessional behavior and commented extensively on it, ultimately imposing a

\footnotetext{
${ }^{130}$ Id. at 92 .

${ }^{131}$ Id.

${ }^{132} I d$.

${ }^{133}$ Id. at 93.

${ }^{134} \mathrm{Id}$.

${ }^{135} \mathrm{Id}$.

${ }^{136}$ Id. at 86.
} 
discipline based on it that was harsher than any recommendation it is what makes this case stand out in the professionalism movement in Florida. ${ }^{137}$

The court finished with a message clearly not just intended for the defendant in this case which summarized their position on unprofessional behavior as a rule violation:

This Court has been discussing professionalism and civility for years. We do not tolerate unprofessional and discourteous behavior. We do not take any pleasure in sanctioning Norkin, but if we are to have an honored and respected profession, we are required to hold ourselves to a higher standard. ${ }^{138}$

While some have lauded the professionalism focus by the Court in interpreting the Rules Regulating the Florida Bar, there are others who just flat out believe the Florida Supreme Court got it wrong. ${ }^{139}$ Critics have said that "It does not matter if Norkin is obnoxious or his advocacy for clients is too aggressive." 140 They see Norkin's right to speak freely in his representation ass a free speech issue, which the Court cannot ignore simply because Norkin is a lawyer. ${ }^{141}$ They claim the court is interpreting the rules wrong, ignoring a United States Supreme Court dictating when an attorney's speech can be limited. ${ }^{142}$ Rather than studying the case as an example of unprofessional behavior, as the court insists, critics say that it should be read as 'glaring example of a court allowing its subjective displeasure with an attorney cloud an objective and unbiased analysis of the facts of the case, the applicable disciplinary rules and court decisions that protect an attorney's free speech rights under the first amendment." ${ }^{143}$ In short, the belief is that Norkin

\footnotetext{
${ }^{137}$ Id. at 93.

${ }^{138} \mathrm{Id}$.

139 Paul K. Ogden, Florida Supreme Court Ignores Facts and Law in Suspending Attorney for Two Years for Speech Critical of Another Attorney, DISBARRING THE CRITICS, (June 21, 2015) http://disbarringthecritics.blogspot.com/2014/01/florida-supreme-court-badly-bungles.html.

${ }^{140} \mathrm{Id}$.

${ }^{141} I d$.

${ }^{142} I d$.

${ }^{143}$ Id.
} 
had the right to talk to his opposing counsel and Judges and did not violate the Rules Regulating the Florida Bar, and thus it was improper to sanction him.

It is rare that an attorney is sanctioned more heavily than a Referee or the Florida Bar recommended or requested. ${ }^{144}$ One possible reason why the court came down so hard on $\mathrm{Mr}$. Norkin may lie in the opposing counsel in that matter. The court noted in a footnote that Mr. Brooks, now deceased, was, at the time of the "repugnant communications," 71 years old and had several serious illnesses. ${ }^{145}$ He was a University of Florida honors graduate, and awarded a full scholarship to Harvard Law School. ${ }^{146}$ He served in the US Army in Korea and Vietnam and was awarded a Bronze Star for meritorious service, was AV rated, had a lengthy and unblemished career, and "had never previously filed a grievance against a member of the Florida since his admission in 1965."147

Questions arise about the situation in which the court made its decision. First—what if the opposing attorney had not had such a clean record--had Mr. Norkin used the same tactics on them, would that change the outcome? Is it possible that such an external factor as the opposing party weighed in along with Mr. Norkin's own behavior and record? Would another attorney, who may have acted similarly on occasion to Mr. Norkin have cast the otherwise offending behavior in this bad light, or would they simply have seen their own behavior, perhaps only slightly magnified, reflected back at them at them? Would their own past bad behavior been a mitigating factor in considering Mr. Norkin's sanction?

Second, questions arise regarding the timing of the Norkin decision-- coming just four months after a Florida Supreme Court order creating a focused professionalism movement in

\footnotetext{
${ }^{144}$ See Martocci, supra note 70.

145 Norkin, 132 So. 3d at 93.

${ }^{146} \mathrm{Id}$.

${ }^{147}$ Id.
} 
Florida- calls into question whether their previous actions influenced the court's decision here. This decision came at or near the apex of what may be called a professionalism crisis in Florida. The court itself even offered in dicta that a previous case may have had a rougher sanction were it on the block today. ${ }^{148}$ Was the court simply ripe to deliver a certain message and found Mr. Norkin an ideal vehicle? Or did the case itself, as it progressed from 2011, help drive the professionalism movement?

These questions can never really be answered. However, a closer examination of the professionalism movement in Florida is necessary to get a fuller picture of the state of the crisis in Florida and how the Court, Bench and Bar are handling it. By doing so, attorneys can come to understand the landscape in which they are practicing, and headway can be made in solving the professionalism crisis.

\section{Professionalism in the Spotlight in Florida}

In recent years, the Florida Supreme Court has taken measures to address the decline in civility in the practice of law that they have noted in cases brought before them and acknowledging the public and the Bar's outcry.

\section{A. The Oath of Admissions to the Florida Bar}

One recent step was in 2011, when the Court amended the Florida Bar Oath of Admission, which according to its preamble are the "The general principles which should ever control the lawyer in the practice of the legal profession are clearly set forth in the following oath of admission to the Bar, which the lawyer is sworn on admission to obey and for the willful

${ }^{148}$ Norkin, 132 So. 3d at 93. 
violation to which disbarment may be had." ${ }^{149}$ The oath in full reads as follows, with the latest addition in added bold italics:

I do solemnly swear:

I will support the Constitution of the United States and the Constitution of the State of Florida;

I will maintain the respect due to courts of justice and judicial officers;

I will not counsel or maintain any suit or proceedings which shall appear to me to be unjust, nor any defense except such as I believe to be honestly debatable under the law of the land;

I will employ for the purpose of maintaining the causes confided to me such means only as are consistent with truth and honor, and will never seek to mislead the judge or jury by any artifice or false statement of fact or law;

I will maintain the confidence and preserve inviolate the secrets of my clients, and will accept no compensation in connection with their business except from them or with their knowledge and approval;

To opposing parties and their counsel, I pledge fairness, integrity, and civility, not only in court, but also in all written and oral communications;

I will abstain from all offensive personality and advance no fact prejudicial to the honor or reputation of a party or witness, unless required by the justice of the cause with which I am charged;

I will never reject, from any consideration personal to myself, the cause of the defenseless or oppressed, or delay anyone's cause for lucre or malice. So help me God.

Such addition by the court was intended to counteract two trends that they noted: "Growing concerns in recent years about incivility among attorneys," and that other attorney organizations, such as the American Board of Trial Advocates, "have taken steps to raise the level of awareness about the importance of civility in practicing law." ${ }^{150}$ The court noted that other states have already added such civility pledges to its oaths, among them, South Carolina, Utah, and New Mexico. ${ }^{151}$

The Bar's Lawyer Regulation Department noted after the addition, that there already was a rule in the Rules Regulating the Florida Bar, 4-8.4, that could be used to enforce civility,

\footnotetext{
${ }^{149}$ Oath of Admission, http://www.floridabar.org/tfb/TFBProfess.nsf/basic+view/04E9EB581538255A85256B2F006CCD7D?OpenDocum ent (last visited August 1, 2015).

${ }^{150}$ Jan Pudlow, Revised Admission Oath Now Emphasizes Civility, The Florida Bar News, October 1, 2011.

${ }^{151} I d$.
} 
although it was admitted that the term in the rules was "somewhat vague."152 The new oath, however, made it clear that civility is now "is not aspirational, but enforceable to all those who take the oath." 153 The fact that the Norkin case was decided after this addition gives additional teeth to the Court's decision to impose sanctions for his behavior, as well as reinforcing the message of this Oath addition. ${ }^{154}$

\section{B. Professionalism Expectations}

The Florida Bar Standing Committee on Professionalism published a list of professionalism expectations, approved in 2014 by the Committee and by the Florida Bar Board of Governors in January, 2015. ${ }^{155}$ As of March 2015, these new set of expectations were sent to the conferences for circuit and county court judges, and were on their way to the Florida Supreme Court to receive their approval before being disseminated to Bar sections and local bar groups. ${ }^{156}$ These superseded a set of standards that were submitted to the Board of Governors 1989, which were amended to "The Ideals of Goals and Professionals," adopted by the Board of Governors in 1990 as an aspirational set of guidelines. ${ }^{157}$ It is clear message of the attention that the Bar is paying to the crisis of professionalism, as these standards remained unchanged for 24 years. $^{158}$

The 1990 aspirational list of behaviors for professionalism were:

1. Commitment to Equal Justice under Law and the Public Good

2. Adherence to a Fundamental Sense of Honor, Integrity, and Fair Play

3. Honesty and Candor

4. Fair and Efficient Administration of Justice

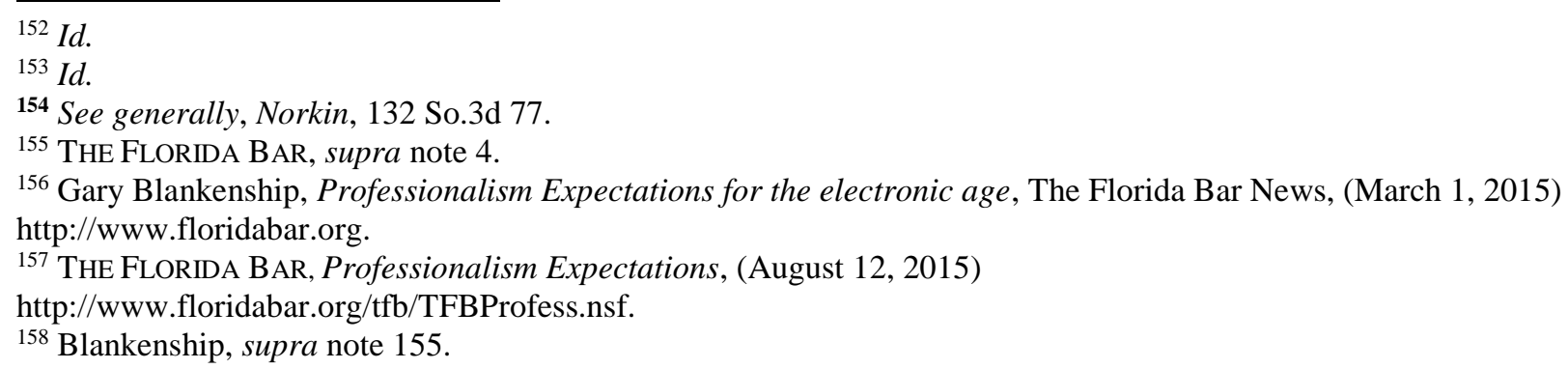


5. Courtesy

6. Respect for the Time and Commitments of Others

7. Independence of Judgment

These behaviors were meant to demonstrate the "importance of professionalism as the ultimate hallmark of the practice of law," and the Center for Professionalism was charged with the purpose to "enunciate non-mandatory standards of professional conduct and encourage adherence thereto." 159 These standards were clearly marked has having aspirations higher than those required by the Rules of Professional Conduct, and thus were adopted then as aspirational guidelines ${ }^{160}$ However, in recent years, the Florida Bar Standing Committee on Professionalism was called upon to create new guidelines and the implementation of a code for resolving professionalism complaints in 2013, approved in 2015.

These expectations, available on the Florida Bar website, attributes its guidance to two sources_-both the Rules Regulating the Florida Bar and the "long standing customs of fair, civil and honorable legal practice in Florida." ${ }^{161}$ In reading the expectations, one can determine if language originates from the Rules if the expectation is stated "as an imperative" using terms such as "must" or "must not."162 By contrast, where the expectations originate from a custom and not an ethical rule that would lead to discipline if violated, the expectation will read "should" or "should not."163

According to the Bar, the definition of lawyer professionalism is ${ }^{164}$ :

1. Embracing a commitment to serve others

2. Dedicating to properly using knowledge and skills to promote a fair and just result

3. Endeavoring to enhance knowledge, skills and competence,

4. Ensuring that concern for a client's desire result does not subvert the lawyers' fairness honesty civility respect and courtesy during

${ }^{159}$ THE FLORIDA BAR, Rule 19.1-1: Purpose, (last visited August 13, 2015) http://www.floridabar.org. ${ }^{160} I d$.

${ }^{161}$ THE FLORIDA BAR, supra note 156.

${ }^{162} I d$.

${ }^{163} \mathrm{Id}$.

${ }^{164} I d$. 
interactions with fellow professionals, clients, opponents, public officials, members of the judiciary, or the public

5. Contributing skill knowledge and influence to further the profession's commitment to service and the public good including efforts to provide all persons, regardless of their means or popularity of their causes with access to the law and the judicial system

6. Enhancing the legal systems reputation by education the public about the profession's capabilities and limits specifically about what the legal system can achieve and appropriate methods of obtaining those results and

7. Accepting responsibility for one's own professional conduct and the conduct of others in the profession, including encouraging other lawyers to meet these civility and Professionalism Expectations and fostering peer regulation to ensure that teach lawyer is competent and public-spirited. ${ }^{165}$

Those critics that have taken the position that disciplining for professionalism violations is impossible should take note of these clear and definite definitions that the Bar has provided. In addition to the definition in the preamble, the Bar specifically adopted seven sets of expectations, enumerated carefully. ${ }^{166}$ The first set of expectations is "Commitment to Equal Justice under the Law and to the Public Good," which has 13 specific points about what is expected of lawyers. This set of expectation is meant to emphasize that "a license to practice law is a privilege" which among other responsibilities, requires a lawyer to "use that position to promote the public good and to foster the reputation of the legal profession." 167 These 13 points intersperse expectations originating from customs as well as imperatives from the Rules, and cite to eight different Rules Regulating the Florida Bar in shaping its imperatives. ${ }^{168}$

The second set of expectations concern "Honest and Effective Communication" and contains a list of 18 specific expectations, again drawing both from customs and rules. ${ }^{169}$ The Rules Regulating the Florida Bar are cited 13 times in laying out lawyers obligations with regard

\footnotetext{
${ }^{165} \mathrm{Id}$.

${ }^{166} \mathrm{Id}$.

${ }^{167}$ Id.

${ }^{168} \mathrm{Id}$.

${ }^{169} \mathrm{Id}$.
} 
to communication. ${ }^{170}$ Potential pitfalls that did not even exist the last times these Ideals were considered are specifically addressed, such as several expectations of behavior and rules regarding social media. ${ }^{171}$ The third set of expectations are titled "Adherence to a Fundamental Sense of Honor, Integrity, and Fair Play" and are explained that "courtesy, cooperation, integrity, fair play and abiding by a sense of honor are paramount for preserving the integrity of the profession." ${ }^{172}$ Although this set of 18 expectations seem to be directly connected to the aspirational concept of professionalism, there are actually seven of the 18 that specifically quote Rules Regulating the Florida Bar with "must" or "must not language" at its root. ${ }^{173}$ The fourth set of professionalism expectations consider the "Fair and Efficient Administration of Justice," with 20 different enumerated expectations, four of them citing to rules. ${ }^{174}$

The fifth set of expectations specifically tackles what many have considered vague or problematic areas in defining or governing professional behavior- "Decorum and Courtesy."175 The explanation of this section stress its importance, "When lawyers display reverence for the law, the judicial system and the legal professional by acting with respect, decorum and courtesy, they earn the trust of the public and help to preserve faith in the operation of a fair judicial system." ${ }^{176}$ There are 10 detailed expectations, with only one here citing to the Rules Regulating the Florida Bar. The sixth set of expectations are "Respect for Time and Commitments of Others" with 10 more detailed expectations also referring to one rule. ${ }^{177}$ The last set of

\footnotetext{
${ }^{170} I d$.

${ }^{171} I d$.

${ }^{172} I d$.

${ }^{173} I d$.

${ }^{174} I d$.

${ }^{175} I d$.

${ }^{176} \mathrm{Id}$.

${ }^{177} I d$.
} 
expectations are titled "Independence of Judgment" and contain six expectations of professionalism, again, one of them tied to the Rules Regulating the Florida Bar. ${ }^{178}$

While some will argue that some of these expectations of behavior are too vague to be enforceable beyond aspirations, they actually are clearly defined, even in the last three sets, where there are more "shoulds" than "musts." For many attorneys the problem. By stating these expectations in a clear and straightforward manner, lawyers can now be on notice that their decorum, respect for others and judgment are part of their responsibilities of the profession, not just a general hope for behavior.

In sum, this set of expectations has the potential to show current lawyers - and to teach new ones--that the Florida Bar does not hope that lawyers don't "impose arbitrary or unreasonable deadlines on others" or "refer to all parties, witnesses, and other counsel by their last names" -it expects those formal and courteous behaviors. By mixing in specific actions that are already current disciplinary offenses with those that are not codified in the Rules Regulating the Florida Bar, these new expectations can make lawyers understand that these behaviors are grouped together purposefully to close that gap between aspirational behavior and the bottom level of acceptable behavior that if violated would result in sanctions. When the expected conduct (at risk for discipline under the Rules Regulating the Florida Bar) and the aspirational conduct are intermingled, we set one set of expectations for attorneys, while maintaining as system of discipline rooted in rule enforcement. Such as shift in what is demanded of lawyers can help improve how attorneys view their responsibilities.

Complaints persist by critics as to the vagueness of professionalism. These critics should be dismissed. First, it is possible to define what is expected of lawyers, and second, it is possible to clearly let lawyers know what is expected of them. In reading the cases in which lawyers have ${ }^{178} I d$. 
been disciplined or considered for discipline for decorum, civility, courtesy or other "aspirational professionalism behaviors" it seems unlikely that that the lawyer thought their behavior was pleasant, civil, or respectful. It seems more likely, and it some cases, established, that they knew their behavior was rude - but likely believed the rules did not prohibit them from acting in that manner. In weighing their behavior, they likely decided that the possible gain, whether for their clients, or personal, that could be had from intimidating, bullying, or behaving badly in some manner simply outweighed any risks. Their motivations—goal oriented - allowed themselves to behave unprofessionally. If we have goal oriented professionalism, we can use that motivation to push them into behaving well instead.

In New Jersey, such question of whether unprofessional behavior was understood was put to the test. In a case involving attorney Jared Stolz, he engaged in clearly unprofessional behavior that resulted in a complaint against him. ${ }^{179}$ His behavior included discriminatory name calling against another attorney as well as specifically stating, among other comments, “"Did you get beat up in school a lot? Because you whine like a little girl." 180 While this conduct was ultimately combined with misrepresentations to a judge regarding received documents (which clearly violated disciplinary based rules of conduct) Stolz stipulated that he made all of the statements involved. ${ }^{181}$ If the first worry about discipline stemming from professionalism violations is defining unprofessional behavior, this case illustrates that this is not the problem. There seems no chance that this lawyer did not know that calling someone a "f-g" was inappropriate in the context of a case, much less in any context. It seems impossible that he didn't believe that saying to another attorney "Put both your email addresses in my 'Junk Mail'

\footnotetext{
${ }^{179}$ Lee Moran, New Jersey lawyer suspended for three months for 'discriminatory' remarks to an opposing counsel, DAILY NEWS, (Date, time), http://www.nydailynews.com/new-york/nyc-crime/new-jersey-lawyer-suspendedmonths-discriminatory-remarks-opposing-counsel-article-1.1937473.

${ }^{180} I d$.

${ }^{181} I d$.
} 
box, because that is all I get from you, JUNK" was unprofessional either. ${ }^{182}$ What he probably did believe — and may have been correct — was that those statements may not have violated any "floor" ethical discipline rules — anything that could result in discipline for him. Therefore, he may have made the decision that being rude, intimidating, discriminatory and sarcastic might get him what he wanted in his case. The unprofessional behavior was clear, but the expectations of how lawyers are to practice has not been, allowing unprofessional statements and behavior to be knowingly made and used as weapons as no rules are set up to stop them. We must close the gap between expectations and the floor level of discipline to remove the ability to use unprofessionalism as a tactic in winning cases.

\section{SC12-688 In Re: Code for Resolving Professionalism Complaints}

In June 2013, the Florida Supreme Court, at the urging of the Court's Commission on Professionalism, adopted a Code for Resolving Professionalism Complaints. ${ }^{183}$ In issuing SC13688 , the Court, after establishing jurisdiction, gave a brief history of the professionalism movement in Florida including early reports and commissions designed to help combat the "steep decline" in lawyer professionalism. ${ }^{184}$ They discussed that while Florida had traditionally had a more "passive, academic" approach to improve professionalism, and that the past two years of study probably had a positive impact, "affirmative practical" steps were now needed. ${ }^{185}$ The purpose of SC13-688 is to bring the professionalism problem to the front burner. ${ }^{186}$ In this order, the Court did not adopt an entirely new "Code of Professionalism" but rather, as a first step to encourage good behavior, related an integrated standard regarding

\footnotetext{
${ }^{182} \mathrm{Id}$.

${ }^{183} \mathrm{http}: / / \mathrm{www}$. floridasupremecourt.org/decisions/2013/sc13-688.pdf

${ }^{184} \mathrm{Id}$.

${ }^{185} \mathrm{Id}$.

${ }^{186}$ Circuit Professionalism Report, Henry Latimer Center for Professionalism (professional Programs Presented from July 1, 2013 through February 1, 2014) www.flabar.org (last visited July 30, 2015).
} 
professionalism gleaned from sources already in existence, collected and promulgated in one integrated format. ${ }^{187}$ The Supreme Court stated that the existing five sources were key:

1. The Oath of Admission to the Florida Bar

2. The Florida Bar Creed of Professionalism

3. The Florida Bar Ideals and Goals of Professionalism (late revised in 2015 adoption)

4. The Rules Regulating the Florida Bar

5. The Decisions of the Florida Supreme Court ${ }^{188}$

The order notes that all of these were been previously adopted, and in existence for many years, but had not been placed in "one location as our standard of expected professional behavior." 189 Attached to this order was a "Code for Resolving Professionalism Complaints."190

The Code defined unprofessional conduct as "substantial or repeated violations" of the Oath, Creed Ideals and Goals, Rules and decisions of the Court. ${ }^{191}$ The court also noted that unprofessional conduct will "in many instances" be a violation of the Rules of Professional Conduct, singling out breaches of Rule 4-8.4(d) of the Rules Regulating the Florida Bar as a previous basis for imposing discipline, and citing to cases in which such violations occurredThe Florida Bar v. Ratiner, The Florida Bar v. Abrahamson, and The Florida Bar v. Martocci, all discussed supra. ${ }^{192}$

The Code lays out implementation procedures for bringing professionalism complaints, including definitions of all the parties involved, and the process to do so. ${ }^{193}$ Of note is the process for initiating a complaint, which may be by any person, thorough a Local

\footnotetext{
${ }^{187}$ Supra note 183

${ }^{188}$ Id.; Note: many of these sources were suggested back in 2005 by a scholar as ways to move a definition more clearly See Rizzardi, supra note 7.

${ }^{189} \mathrm{http}: / /$ www.floridasupremecourt.org/decisions/2013/sc13-688.pdf

${ }^{190} I d$.

${ }^{191} I d$.

${ }^{192} I d$.

${ }^{193} \mathrm{Id}$.
} 
Professionalism Panel (discussed below) when available and appropriate, or through the Attorney Consumer Assistance and Intake Program (ACAP), the stage one intake program in the formal discipline process. ${ }^{194}$

In January of 2015, the order was amended to handle a concern that faced those involved in the professionalism process. ${ }^{195} \mathrm{~A}$ section on immunity was added to "provide immunity from civil liability members of the Local Professionalism Panels and members of the Circuit Committees on Professionalism, as well as to staff persons for these entities, for all acts performed in the course of their official duties." ${ }^{196}$ The addendum was made after further study by the Supreme Court Commission on Professionalism, and on the court's own motion. ${ }^{197}$

\section{Local Professionalism Panels}

Of particular interest the new push for professionalism programs is the creation by the court of Local Professionalism Panels. These panels are defined in the Code for Resolving Professionalism Complaints as "An entity independent of the Florida Bar which is establish at the local level for the purpose of resolving complaints of alleged unprofessional conduct by attorneys practicing in that circuit. ${ }^{198}$ Historically, an Administrative Order from 1998 required the Chief Judge of each circuit to create and maintain a Circuit Committee on Professionalism. ${ }^{199}$ In additional to these previously existing bodies, the court adopted the Local Professional Panel Plan, in which the Chief Judge of every circuit was directed to create a Local Professional Panel

\footnotetext{
${ }^{194} I d$.

${ }^{195} \mathrm{http}: / /$ www.floridasupremecourt.org/decisions/2015/sc15-75.pdf

${ }^{196} I d$.

${ }^{197} I d$.

${ }^{198}$ Supra note 183 http://www.floridasupremecourt.org/decisions/2013/sc13-688.pdf

${ }^{199}$ Fifth Judicial Circuit Court of Florida, Fifth Circuit Professionalism Committee, (July 30, 2015) http://www.circuit5.org/c5/programs-services/professionalism-committee/.
} 
(LPP) to "receive and resolve professionalism complaints" in an informal manner where possible. $^{200}$

Each circuit in Florida has implemented circuit specific "Local Professionalism Panels," (LPP) to comply with this June 2013 order. ${ }^{201}$ These panels hear grievances against lawyers whose actions violated accepted standards of professionalism and civility. ${ }^{202}$ They are designed to "educate attorneys whose behavior although perhaps not subject to formal discipline under the Florida Bar's grievance system, does not comply with the standards of professionalism and civility expected among members of the Bar."203

In September 2014, information on how to reach these panels was disseminated statewide to lawyers. ${ }^{204}$ Local panels are designed to handle "informally less serious" matters while the intake system of the Bar's Disciplinary System, the Attorney Consumer Assistance Program will "continue to handle more serious allegations that could result in disciplinary action for unprofessional conduct.” ${ }^{205}$ The contact information for the local panels varies-in some circuits, there are multiple people or organizations to reach, while in some, a single lawyer may be reached by email or phone. ${ }^{206}$ If a professionalism complaint is referred to ACAP, that program can resolve the complaint informally through the LPP or refer it to the Florida Bar's Lawyer regulation Department for further action if warranted ${ }^{207}$

\footnotetext{
${ }^{200}$ Supra note 183

${ }^{201}$ Professionalism Enforcement Program in Place for S. Florida, Florida Bar News May 14, 2014 https://www.floridabar.org/_85256AA9005B9F25.nsf/0/CB6C7C03086E509085257CCF004A5692?OpenDocume nt

${ }^{202} I d$.

${ }^{203} \mathrm{Id}$.

${ }^{204}$ Contact Info for Local Professionalism Committees is Now Available, Florida Bar News September 1, 2014 at 9. ${ }^{205} \mathrm{Id}$.

${ }^{206} \mathrm{Id}$.

${ }^{207}$ Supra note 183
} 
Comparative to the formal discipline process, to which a complaint may be referred, the LPPs are informal bodies, each slightly different in their creation and operation. ${ }^{208}$ Below is a chart of each of the twenty circuits in Florida summarizing their LPP creations to satisfy the new directive by the Florida Supreme Court:

\begin{tabular}{|c|c|c|c|}
\hline Circuit & $\begin{array}{l}\text { Administrative } \\
\text { Order }\end{array}$ & Overview of Order and Citation & $\begin{array}{l}\text { Membership } \\
\text { Composition }\end{array}$ \\
\hline First & No. 2013-46 & $\begin{array}{l}\text { The First Judicial Circuit Bench and Bar } \\
\text { Professionalism Committee shall be } \\
\text { designated as the "Local Professionalism } \\
\text { Panel" and "shall adopt a structured } \\
\text { mechanism to receive, screen and resolve } \\
\text { professionalism complaints" } 209\end{array}$ & $\begin{array}{l}\text { Not designated } \\
\text { specifically in order }\end{array}$ \\
\hline Second & No. 2013-09 & $\begin{array}{l}\text { The Second Judicial Circuit } \\
\text { Professionalism committee is "re- } \\
\text { constituted" as the Second Judicial } \\
\text { Circuit Professionalism Panel whose } \\
\text { purpose is to "receive, screen, evaluate } \\
\text { and act upon complaints of conduct } \\
\text { inconsistent with the Standards of } \\
\text { Professionalism as defined by the } \\
\text { Supreme Court opinion, and resolve } \\
\text { those complaints informally, if possible } \\
\text { or refer them to the Florida Bar if } \\
\text { appropriate or necessary"210 The Panel } \\
\text { will also assess the status of } \\
\text { professionalism in the second circuit and } \\
\text { encourage and develop educational } \\
\text { programs to promote Professionalism. }\end{array}$ & $\begin{array}{l}\text { Not less than } 20 \text { and } \\
\text { not more than } 40 \\
\text { members selected } \\
\text { and appointed by the } \\
\text { Chief Judge, } \\
\text { considering a cross- } \\
\text { section of the Circuit } \\
\text { including geographic } \\
\text { location, diversity, } \\
\text { professional } \\
\text { reputation and bar } \\
\text { activity } \\
\text { consideration. }\end{array}$ \\
\hline Third & No. 2013-011 & $\begin{array}{l}\text { The Third Judicial Circuit Joint } \\
\text { Bench/Bar Professionalism Committee is } \\
\text { reconstituted as the "Third Judicial } \\
\text { Circuit Professionalism Panel and } \\
\text { committee, specifically designed to act } \\
\text { as the LPP. Its purpose is to meet with } \\
\text { attorney who have not had conduct }\end{array}$ & $\begin{array}{l}\text { Specifically designates } \\
9 \text { members: } \\
\text { 1. } 2 \text {. Third Judicial } \\
\text { Circuits' rep to Fla. } \\
\text { Bar Board Governors } \\
\text { and Young Lawyers } \\
\text { Division } \\
\text { Representative }\end{array}$ \\
\hline
\end{tabular}

${ }^{208} \mathrm{Id}$.

${ }^{209}$ Administrative Order 2013-46 First Judicial Circuit of the State of Florida, (June 2013) www.firstjudicialcircuit.org.

${ }^{210}$ Administrative order 2013-10 Second Judicial Circuit of the State of Florida (December 2013) http://2ndcircuit.leoncountyfl.gov/adminOrders.php 


\begin{tabular}{|c|c|c|c|}
\hline & & $\begin{array}{l}\text { consistent with the Standards of the } \\
\text { Third Circuit Bar Association. }{ }^{211}\end{array}$ & $\begin{array}{l}\text { 3. President Third } \\
\text { Judicial Circuit Bar } \\
\text { Association } \\
\text { 4. State Atty or } \\
\text { designee } \\
\text { 5. Public Defender or } \\
\text { designee } \\
\text { 6. Member judiciary } \\
\text { 7. At large member } \\
\text { selected by the BOG } \\
\text { representative } \\
\text { 8.At large member } \\
\text { selected by Bar } \\
\text { Association President } \\
\text { 9. At large member } \\
\text { selected by the } \\
\text { judiciary member }\end{array}$ \\
\hline Fourth & No. 2013-09 & $\begin{array}{l}\text { The Professionalism Review Program is } \\
\text { reconstituted at the LPP whose purpose } \\
\text { is to address attorneys who have } \\
\text { conducted themselves in a way that "is } \\
\text { inconsistent with the standards of } \\
\text { professionalism" in an informal, non- } \\
\text { punitive, educational and constructive } \\
\text { manner. }\end{array}$ & $\begin{array}{l}\text { Chairperson and up } \\
\text { to five members of } \\
\text { the Jacksonville Bar } \\
\text { Association, selected } \\
\text { by the LPP } \\
\text { Chairperson and the } \\
\text { President of the JBA } \\
\text { with approval of } \\
\text { Chief Judge. }\end{array}$ \\
\hline Fifth & No. A-2013-45 & $\begin{array}{l}\text { Each county in the Fifth circuit is to } \\
\text { establish a LPP which will operate under } \\
\text { the Fifth Circuit Professionalism } \\
\text { Committee. Each county LPP will have a } \\
\text { liaison to the professionalism } \\
\text { Committee. The LPP shall investigate } \\
\text { professionalism complaints against a } \\
\text { member of the Florida Bar that have } \\
\text { been initiated through the LPP or the bar } \\
\text { discipline system but participation and } \\
\text { appearance. }\end{array}$ & $\begin{array}{l}\text { Specific order to } \\
\text { each county dictates } \\
\text { that the LPP consists } \\
\text { of one Judge or } \\
\text { Senior Judge from } \\
\text { that county as chair, } \\
\text { and no fewer than } \\
\text { two members of the } \\
\text { Florida Bar in good } \\
\text { standing. }\end{array}$ \\
\hline Sixth & $\begin{array}{l}\text { No. 2013-075 } \\
\text { PA/PI-CIR }\end{array}$ & $\begin{array}{l}\text { The Sixth Circuit Professionalism } \\
\text { Committee, which has been addressing } \\
\text { complaints about professionalism } \\
\text { problems on informal basis will continue } \\
\text { to operate, with the chief Judge of the }\end{array}$ & $\begin{array}{l}\text { In addition to the } \\
\text { chair, the twenty } \\
\text { appointments already } \\
\text { in existence from the } \\
\text { previous committee }\end{array}$ \\
\hline
\end{tabular}

${ }^{211}$ Administrative Order 2013-011 Third Judicial Circuit of Florida, (December 2013) http://www.jud3.flcourts.org/AO_Numeric_Order.html

${ }^{212}$ Administrative Order 2013-09 Fourth Judicial Circuit of Florida (August 2013) http://www.jaxbar.org/wpcontent/uploads/2014/04/AO-2013-09-Establishment-of-Local-Prof.-Panel.pdf

${ }^{213}$ Administrative Order 2013-45 Fifth Circuit (November 2013) http://www.circuit5.org/c5/wp-admin/ao/A201345.pdf 


\begin{tabular}{|c|c|c|c|}
\hline & & $\begin{array}{l}\text { Circuit as the Chair of the Committee, } \\
\text { and meet quarterly to discuss the status } \\
\text { of professionalism and its activities, } \\
\text { issue an annual report, offer CLE courses } \\
\text { and hear complaints. }\end{array}$ & $\begin{array}{l}\text { will continue } \\
\text { including Judges, } \\
\text { state attorney, public } \\
\text { defender, bar } \\
\text { presidents, law } \\
\text { school representation } \\
\text { and others. }\end{array}$ \\
\hline Seventh & No. P-2013-188 & $\begin{array}{l}\text { Orders the establishment of a LPP to } \\
\text { address alleged instances of improper } \\
\text { conduct and conduct 'constructive non- } \\
\text { punitive' proceedings, with referrals by } \\
\text { Judges if they choose. A complaint form } \\
\text { and detailed proceedings guidelines are } \\
\text { attached. }\end{array}$ & $\begin{array}{l}\text { Consisting of } \\
\text { respected attorneys } \\
\text { in the community on } \\
\text { a voluntary basis. }\end{array}$ \\
\hline Eighth & No. 10.02 & $\begin{array}{l}\text { Creates the Eighth Judicial Circuit LPP } \\
\text { and designates as the LPP and the Eight } \\
\text { Judicial Circuit Bench/Bar Committee } \\
\text { and the Eight Judicial Circuit } \\
\text { Professionalism Committee to receive, } \\
\text { screen evaluate and act upon complains } \\
\text { of unprofessional conduct and resolve } \\
\text { them informally if possible or refer to the } \\
\text { Florida Bar if appropriate or } \\
\text { necessary. }\end{array}$ & $\begin{array}{l}\text { Consist of not less } \\
\text { than nine and not } \\
\text { more than } 13 \\
\text { members selected } \\
\text { and appointed by the } \\
\text { Chief Judge of the } \\
\text { Eighth Circuit } \\
\text { including the } \\
\text { chairperson. }\end{array}$ \\
\hline Ninth & No. 2014-07 & $\begin{array}{l}\text { Establishes the Ninth Circuit } \\
\text { Professionalism Panel (LPP) to receive, } \\
\text { screen evaluate and act upon such } \\
\text { reasonable complaints of unprofessional } \\
\text { conduct as may be referred to the panel, } \\
\text { given the standards available. A detailed } \\
\text { set of procedures and a sample complaint } \\
\text { form are included. } 217\end{array}$ & $\begin{array}{l}\text { Chair, appointed by } \\
\text { Chief Judge and one } \\
\text { member each of } \\
\text { Central Fla. Women } \\
\text { Lawyers, Paul C } \\
\text { Perkins Bar, } \\
\text { Hispanic Bar of } \\
\text { Central Florida, } \\
\text { American Board } \\
\text { Trial Advocates } \\
\text { Orange County Bar } \\
\text { Association Young } \\
\text { Lawyers, George C } \\
\text { Young Inns of Court, }\end{array}$ \\
\hline
\end{tabular}

${ }^{214}$ Administrative Order 2013-075 PA/Pi-Cir Sixth Judicial Circuit (November 2013) http://www.jud6.org/LegalCommunity/LegalPractice/AOSAndRules/aos/2013PDFFiles/2013-075.pdf ${ }^{215}$ Administrative Order 2013-188 Seventh Judicial Circuit (October 2013) http://www.circuit7.org/Attorney\%20Resources/P-2013-188-Local\%20Professionalism\%20Panel.pdf ${ }^{216}$ Administrative Order 10.02 Eighth Judicial Circuit (January 2014) http://circuit8.org/web/ao/10\%2002\%20(v2)(s)\%20Local\%20Professionalism\%20Panel-signed.pdf ${ }^{217}$ Administrative Order 2014-07 Ninth Judicial Circuit (June 2014) http://www.orangecountybar.org/content/uploads/PDFs/Administrative_Orders/2014-07\%20$\% 20$ order\%20establishing\%209th\%20circuit\%20professionalism\%20panel.pdf 


\begin{tabular}{|c|c|c|c|}
\hline & & & $\begin{array}{l}\text { Central Florid } \\
\text { Family Law } \\
\text { American Inns } \\
\text { Court, Greater } \\
\text { Orlando Asian } \\
\text { American Bar } \\
\text { Association, two } \\
\text { members Osceola } \\
\text { Bar association, } \\
\text { three members } \\
\text { Orange County Bar } \\
\text { Professionalism } \\
\text { Committee, and } \\
\text { three at-large. The } \\
\text { Chief judge may } \\
\text { participate as his/her } \\
\text { discretion. }\end{array}$ \\
\hline Tenth & No $1-48.0$ & $\begin{array}{l}\text { Formally ratifies the Tenth circuit's } \\
\text { Committee on Professionalism as well as } \\
\text { an LPP. Both shall "perform all } \\
\text { responsibilities" established in the } \\
\text { Supreme Court order. }\end{array}$ & $\begin{array}{l}\text { The Chairperson of } \\
\text { the Committee on } \\
\text { Professionalism, one } \\
\text { member of the bar or } \\
\text { a retired judge } \\
\text { selected by the } \\
\text { Chair, and three } \\
\text { members of the bar } \\
\text { or retired judges } \\
\text { selected by the Chief } \\
\text { Judge. }\end{array}$ \\
\hline Eleventh & No. $14-01$ & $\begin{array}{l}\text { Mandates that the Eleventh Judicial } \\
\text { Circuit Professionalism and Civility } \\
\text { Committee will continue to operate to } \\
\text { assess the status of professionalism } \\
\text { among attorney and promote adherence } \\
\text { to the professional standards available. } \\
\text { Additionally, LPPs are established and } \\
\text { charged with receiving, screening and } \\
\text { acting upon complaints of unprofessional } \\
\text { conduct informally to resolve complaints } \\
\text { against attorneys through a set of } \\
\text { extensive rules adopted in an exhibit. }\end{array}$ & $\begin{array}{l}\text { Respected attorneys } \\
\text { in the community } \\
\text { with nominations } \\
\text { taken considering } \\
\text { length time in } \\
\text { practice, board } \\
\text { certification, trial } \\
\text { experience, } \\
\text { reputation and } \\
\text { leadership }\end{array}$ \\
\hline
\end{tabular}

${ }^{218}$ Administrative Order 1-48.0 Tenth Judicial Circuit, (October 2013) http://www.jud10.flcourts.org/sites/all/files/docs/AO_1-48.0.pdf

${ }^{219}$ Administrative Order 14-01 11th Judicial Circuit (February 2014)

https://www.jud11.flcourts.org/documents/Administrative_Orders/02-14-01\%20-

$\% 20$ Eleventh\%20Judicial\%20Circuit\%20Professionalism\%20and\%20Civility\%20Committee\%20and\%20Local\%2

0Professionalism\%20Panel-No\%20Signature.pdf 


\begin{tabular}{|c|c|c|c|}
\hline Twelfth & No. 2014-8.2 & $\begin{array}{l}\text { The existing peer review program is } \\
\text { reorganized into the Local Professional } \\
\text { Panel. The purpose is to review } \\
\text { complaints alleging that attorneys have } \\
\text { exhibited unprofessional conduct in the } \\
\text { practice of law as defined by violations } \\
\text { of various standards, including the } \\
\text { twelfth circuits own standards of } \\
\text { professionalism. In addition, the LPP } \\
\text { will address less substantial or single } \\
\text { violations to these standards previously } \\
\text { handled by the peer review program. }\end{array}$ & $\begin{array}{l}\text { Total of nine } \\
\text { attorneys, with three } \\
\text { appointed by the } \\
\text { President of the } \\
\text { Sarasota Bar } \\
\text { Association, two } \\
\text { Manatee County Bar, } \\
\text { one by the President } \\
\text { South County } \\
\text { Division of Sarasota } \\
\text { Bar and one } \\
\text { practicing in DeSoto } \\
\text { County. All in good } \\
\text { standing with at least } \\
\text { five years of legal } \\
\text { practice. }\end{array}$ \\
\hline Thirteenth & S-2013-071 & $\begin{array}{l}\text { Orders the thirteenth circuit professional } \\
\text { committee to initiate and coordinate } \\
\text { professionalism activities as well as be } \\
\text { responsible for overseeing and training a } \\
\text { subcommittee of that as the LPP. The } \\
\text { LPP will hear complaints brought } \\
\text { regarding the standards available and by } \\
\text { anyone with a detailed process of panel } \\
\text { review and resolution. An LPP Training } \\
\text { Coordinator is specifically named. }{ }^{221}\end{array}$ & $\begin{array}{l}\text { The LPP will include } \\
\text { all Judges appointed } \\
\text { to the subcommittee } \\
\text { and additional } \\
\text { members must be } \\
\text { members in good } \\
\text { standing of the } \\
\text { Hillsborough County } \\
\text { Bar Association and } \\
\text { the Florida Bar and } \\
\text { have been in practice } \\
\text { at least ten years and } \\
\text { "have attained the } \\
\text { highest respect of } \\
\text { their peers and the } \\
\text { judiciary." }\end{array}$ \\
\hline Fourteenth & No. 2013-00-04 & $\begin{array}{l}\text { The combined Bar/Bench committee and } \\
\text { circuit committee on professionalism } \\
\text { shall be chaired by the administrative } \\
\text { civil law judge and shall function as the } \\
\text { LPP. }{ }^{222}\end{array}$ & $\begin{array}{l}\text { Not spelled out in } \\
\text { the order }\end{array}$ \\
\hline Fifteenth & No $2.16-6 / 13$ & $\begin{array}{l}\text { The fifteenth judicial circuit } \\
\text { professionalism council is reconstituted } \\
\text { as the professionalism panel. The panel's }\end{array}$ & $\begin{array}{l}\text { President of PB } \\
\text { County Bar } \\
\text { association, a }\end{array}$ \\
\hline
\end{tabular}

${ }^{220}$ Administrative Order 2014-8.2 12th Judicial Circuit (April 2014) https://www.jud12.flcourts.org/AbouttheCourts/AdministrativeOrders.aspx

${ }^{221}$ Administrative Order S-2013-071 13th Judicial circuit (October 2013) http://www.fljud13.org/Portals/0/AO/DOCS/S-2013-071.pdf

${ }^{222}$ Administrative Order 2013-00-04 14th Judicial Circuit (July 2013) http://www.jud14.flcourts.org/Administrative\%20Orders/Circuit\%20Admin\%20Orders/2013-00-04.pdf 


\begin{tabular}{|c|c|c|c|}
\hline & & $\begin{array}{l}\text { purpose is meet with attorneys who have } \\
\text { conducted themselves in a manner } \\
\text { inconsistent with the ideals or Standards, } \\
\text { to discuss and counsel attorneys to avoid } \\
\text { future conduct. }\end{array}$ & $\begin{array}{l}\text { representative of } \\
\text { Florida bar board of } \\
\text { governors for the } \\
\text { fifteenth circuit, the } \\
\text { chair of the palm } \\
\text { beach county bar } \\
\text { association's } \\
\text { professionalism } \\
\text { committee and three } \\
\text { members of the bar } \\
\text { and/or retired Judges } \\
\text { selected by the Chief } \\
\text { Judge, who may not } \\
\text { be a member, but } \\
\text { who may preside } \\
\text { over the panel }\end{array}$ \\
\hline Sixteenth & No. 2.074 & $\begin{array}{l}\text { Combines the three current local } \\
\text { Bench/Bar Professionalism committees } \\
\text { to form the Sixteenth Judicial Circuit } \\
\text { LPP. Its purpose is to receive screen, } \\
\text { evaluate and act upon complaints of } \\
\text { unprofessional conduct and resolve the } \\
\text { complaints informally or refer them to } \\
\text { the Florida Bar. }\end{array}$ & $\begin{array}{l}\text { Three county judges } \\
\text { and six members of } \\
\text { the Florida Bar, } \\
\text { selected and } \\
\text { appointed by the } \\
\text { chief Judge, } \\
\text { representing a cross } \\
\text { section of the circuit } \\
\text { considering } \\
\text { diversity, geographic } \\
\text { location, legal } \\
\text { practice area, } \\
\text { reputation and bar } \\
\text { activities. }\end{array}$ \\
\hline Seventeenth & $\begin{array}{l}\text { No. 2013-53- } \\
\text { Gen }\end{array}$ & $\begin{array}{l}\text { Establishes a seventeenth judicial circuit } \\
\text { professionalism panel as the Local } \\
\text { Professionalism Panel. The purpose is to } \\
\text { receive, screen, evaluate and act upon } \\
\text { complaints of unprofessional conduct } \\
\text { and resolve complaints informally or } \\
\text { refer to the Florida Bar. }\end{array}$ & $\begin{array}{l}\text { Not less than } 15 \text { or } \\
\text { more than } 21 \\
\text { members selected by } \\
\text { the Chief Judge that } \\
\text { represent a cross } \\
\text { section of the circuit } \\
\text { with consideration to } \\
\text { geographic location, } \\
\text { diversity, discipline, } \\
\text { reputation or bar }\end{array}$ \\
\hline
\end{tabular}

${ }^{223}$ Administrative Order No. 2-105/6/13 15th Judicial Circuit (June 2013) http://15thcircuit.co.palmbeach.fl.us/web/guest/adminorders

${ }^{224}$ Administrative Order No. 2.074 16th Judicial Circuit (December 2014) https://gov.propertyinfo.com/flmonroe/Other/adminorders.html

${ }^{225}$ Administrative Order 2013-53-Gen 17th Judicial circuit (December 2013)

http://www.17th.flcourts.org/index.php/rules-and-policies/general-orders 


\begin{tabular}{|c|c|c|c|}
\hline & & & $\begin{array}{l}\text { activities. The chief } \\
\text { judge may preside } \\
\text { over the panel but } \\
\text { not be a member. } 15 \\
\text { members are named } \\
\text { in the appendix. }\end{array}$ \\
\hline Eighteenth & No $14-30$ & $\begin{array}{l}\text { Establishes a separate Local Professional } \\
\text { Panel for Brevard and Seminole counties } \\
\text { in the circuit. The panel is an entity } \\
\text { independent of the Florida Bar, and } \\
\text { established locally to resolve complaints } \\
\text { of alleged unprofessional conduct } \\
\text { amongst members of the Bar practicing } \\
\text { in the circuit. Each county will have a } \\
\text { panel under the guidance of the Chief } \\
\text { Judge and Professional Committee of the } \\
\text { circuit. Process and a sample complaint } \\
\text { form are attached. }\end{array}$ & $\begin{array}{l}\text { No less than seven } \\
\text { members of the } \\
\text { Florida Bar in good } \\
\text { standing in each } \\
\text { county, with the } \\
\text { chair selected by the } \\
\text { Chief Judge of the } \\
\text { court. }\end{array}$ \\
\hline Nineteenth & No. 2013-14 & $\begin{array}{l}\text { Designates the Nineteenth Judicial } \\
\text { Circuit Professionalism Panel as the } \\
\text { Local Professionalism Panel. The panel's } \\
\text { purpose is to review complaints and } \\
\text { other intake terms, meet with attorneys } \\
\text { who may have conducted themselves } \\
\text { inconsistently with the standards of } \\
\text { professionalism in order to discuss } \\
\text { conduct and counsel them to avoid future } \\
\text { conduct inconsistent with the existing } \\
\text { standings } 227\end{array}$ & $\begin{array}{l}\text { The members of the } \\
\text { executive board of } \\
\text { the panel shall be the } \\
\text { circuit committee on } \\
\text { professionalism. A } \\
\text { five member } \\
\text { executive board } \\
\text { selected by the chief } \\
\text { judge, who may not } \\
\text { be a member of the } \\
\text { panel. Term lengths } \\
\text { and service are } \\
\text { detailed but not the } \\
\text { membership } \\
\text { otherwise. }\end{array}$ \\
\hline Twentieth & No. 2.20 & $\begin{array}{l}\text { A previously existing peer review } \\
\text { program and committee will now be } \\
\text { known as the Local Professionalism } \\
\text { Program and Local Professional Panel. } \\
\text { The purpose of the panel is improve the } \\
\text { level of professional performance and } \\
\text { competence of lawyers, but is not a } \\
\text { disciplinary proceeding. It is intended to }\end{array}$ & $\begin{array}{l}\text { Comprised of non- } \\
\text { Judicial members of } \\
\text { the professionalism } \\
\text { committee. The chair } \\
\text { shall be a president } \\
\text { or designee of one of } \\
\text { the local bar } \\
\text { associations selected }\end{array}$ \\
\hline
\end{tabular}

\footnotetext{
${ }^{226}$ Administrative Order No. 14-30 18th Judicial Circuit (July 2014) http://brevardclerk.us/_cache/files/ce37a0d90cf7-4ca4-9587-379ccf0111a9/14-30.pdf

${ }^{227}$ Administrative Order No. 2013-14 19th Judicial Circuit (December 2013)

http://www.circuit19.org/cadmin/aorders.html
} 


\begin{tabular}{|l|l|l|}
\hline & $\begin{array}{l}\text { be an educational, informal, non-punitive } \\
\text { program for the practice of law. }\end{array}$ & $\begin{array}{l}\text { by the LPP. No } \\
\text { judges may serve on } \\
\text { the LPP }\end{array}$ \\
\hline
\end{tabular}

The circuit-specific operation of these LPPs clearly has some benefits and drawbacks, as well as similarities and differences in the way that they operate. There are clearly some commonalities among the LPPs. The main commonality among these LPP's is the inability of them compel attorneys to appear before them, or to have any power to discipline them. This feature is clearly what distinguishes the Florida Bar's professionalism efforts from its discipline system. While LPPs are given the power to refer cases they may deem fit to the attorney discipline system, these panels are clearly voluntary processes for the attorneys brought before them.

Another key commonality is the desire for these panels to overall improve the quality of practice in their circuits, through education and grass roots discussions to help attorneys work better together. It is also the universal hope that these panels may intervene through their efforts before any behavior by an attorney may further deteriorate, and an attorney finds him or herself conducting themselves in ever worsening manners and getting caught in the system of attorney discipline without a positive way out. ${ }^{229}$

There are however, operational differences in these circuit programs which may cause challenges to the statewide professionalism efforts going forward. One source of these differences lies in the history of professionalism programs in each circuit. Some of these circuits took existing professionalism programs and administratively renamed them, confident that they were already meeting the needs of the Supreme Court order, and are operating nearly as they

\footnotetext{
${ }^{228}$ Administrative Order No. 2.20 Twentieth Judicial Circuit (February 2013) http://www.ca.cjis20.org/pdf/ao/ao_2_20.pdf

${ }^{229}$ Megan Zavieh, Recovery After Bar Discipline, Attorney at Work (July 25, 2015) http://www.attorneyatwork.com/recovery-bar-discipline/.
} 
have in the past. Others created whole programs to comply. Yet a third group of circuits took existing programs and modified them to adapt to the new requirements.

Another set of differences is highlighted by examining the membership of each of these committees. Each circuit may determine who can best represent the interests of professionalism locally, with incredibly diverse results. In some circuits, the Chief Judge must preside over the LPP. Yet in others, the chief judge — or in some instances—any judge — must not be part of the process. And yet in others, the Chief Judge may make selections but not be a member, and yet in additional circuits, may have the option of participating. Some circuits have prescribed the membership to the person — specifically naming people to be on the LPP. Others have clearly delineated the specifics of whom those people should be, by noting which organizations should be represented in which proportions. Some circuits set minimum requirements as to years of practice or standing with the Bar.

Some LPPs are set up with a general guideline of the number of lawyers that must serve-which also varies greatly. There are as few as three lawyers required by some circuit LPPs, while others allow up to dozens - with many circuits simply setting a range to be filled in. Some panels may select its own leadership, while the leadership of others is more tightly controlled by specifically named parties. The result is the LPPs developed in response to the Supreme Court order are as diverse as the definition of professionalism itself.

There are potential pitfalls given the diversity of these creations. First, given the creation of 20 different LPPs, there is the possibility of such a wide variety of interpretations of the professionalism standards that the code is simply too vague and thus could be considered void. ${ }^{230}$ If different sets of expectations are getting established within each circuit, questions could arise

\footnotetext{
${ }^{230}$ Keith W. Rizzardi, Redefining Professionalism? Florida' Code Mandating the Aspirational Raises Challenging Questions 87 Fla. B.J. 38 (Nov. 2013).
} 
about lawyers acclimating to one set of standards of professionalism expectations, then practicing in another circuit, where they have been interpreted differently. ${ }^{231}$

Second, it was noted that with the many differences statewide, the process for handling complaints was expected to be developing differently locally. ${ }^{232}$ But the practice of law is becoming more geographically diverse, not more localized. While it may have been true that years ago one was a "[insert county/circuit name here] lawyer," many attorneys are now finding themselves practicing all over the state as well as the country. If they cannot even rely on one system governing professionalism throughout their own state, attorneys' may become very complex in day to day transactions. With circuits taking different approaches to the operation of panels statewide, attorneys who practice in multiple circuits may find it difficult to master how each operates, resulting in frustration by lawyers, and disinclination to participate in this voluntary process.

While there is no question that the common goal of each local professionalism panel is not discipline, but rather to promote the "highest ideals of lawyering," one question is whether this state-wide fractioning of the system makes sense in this increasingly global economy. ${ }^{233}$ After all, when the NY Bar is moving to a uniform bar exam for its state applicants, is establishing 20 different professionalism panels in Florida moving in the opposite direction ? $^{234}$

But at the same time the local nature of these panels may cause challenges, it is also expected and makes sense within Florida. Despite the increasingly global nature of practice, Florida is still an incredibly diverse state. Each circuit faces its own challenges due to geography and density of lawyers, among other factors. As of June 1, 2014, the number of lawyers

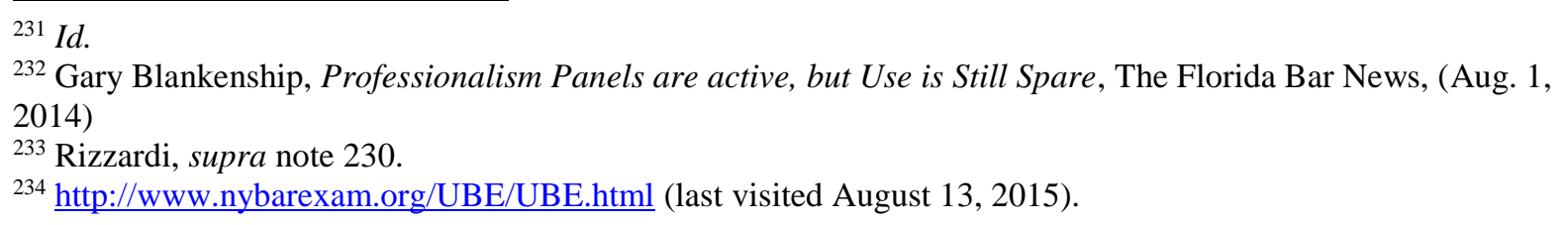


practicing throughout Florida varied dramatically. In Miami-Dade County there were nearly 15,000 lawyers, and Broward County had more than 9,000. ${ }^{235}$ However, Glades County claimed only 3 practicing lawyers, and Liberty and Lafayette Counties listed 1 each. ${ }^{236}$ Why shouldn't the processes for handling professionalism in these respective circuits be tailored to these differences? Despite globalization, the state clearly is a jurisdiction that locally retains different needs and norms in practice. ${ }^{237}$

As of August, 2014, the Florida Bar News was reporting that professionalism panels had been set up but were not being used widely. ${ }^{238}$ At the time of writing, however, the attorney consumer assistance program (ACAP) had around 250 pending complaints regarding unprofessional actions by lawyers, while fielding more than 1600 inquiries involving professionalism behavior. ${ }^{239}$ Those involved in the efforts both local and statewide, were optimistic that progress would be made to better handle complaints both at the Bar and local level and that the process, after settling in, would be a positive effect. ${ }^{240}$ So far, that effect is still somewhat slow but visible in some circuits, as studied recently by the Florida Bar.

The Supreme Court Commission on Professionalism continues to examine and discuss the LPPs to ensure a smooth operation. One amendment, for example, discussed earlier, was the addition of language guaranteeing immunity for official acts of those serving on these panels. Second, the Commission also reviews summary reports to the Supreme Court from each circuit

${ }^{235}$ The Florida Bar News, August 1, 2014 at 6.

${ }^{236} I d$.

${ }^{237} I d$.

${ }^{238}$ Blankenship, supra note 232

${ }^{239} I d$.

${ }^{240} I d$. 
on professionalism incidents on a pre-printed form asking specific information from preselected categories. $^{241}$ For the final quarter of 2014 , the LLPs reported as follows:

\begin{tabular}{|c|c|c|c|}
\hline $\begin{array}{l}\text { Circuit } \\
\text { Number }\end{array}$ & $\begin{array}{l}\text { Number of } \\
\text { Complaints }\end{array}$ & Nature of Complaints/Source & $\begin{array}{c}\text { Disposition and } \\
\text { Other Information } \\
\text { Provided } \\
\end{array}$ \\
\hline 1 & 0 & N/A & $\begin{array}{l}\text { LPP have been } \\
\text { formed and are ready } \\
\text { to receive complaints, } \\
\text { but none received to } \\
\text { date. }\end{array}$ \\
\hline 2 & 0 & N/A & \\
\hline 3 & 0 & N/A & \\
\hline 4 & 3 & $\begin{array}{l}\text { 1 Unprofessional Conduct, } 1 \\
\text { Honesty, integrity, candor, } 1 \text { Bullying } \\
\text { or badgering/1 from client, } 2 \text { from } \\
\text { lawyers }\end{array}$ & $\begin{array}{l}2 \text { complaints had } \\
\text { consultation } \\
\text { completed }\end{array}$ \\
\hline 5 & 0 & N/A & \\
\hline 6 & 0 & N/A & $\begin{array}{l}\text { Jan-March } 2015 \\
\text { (4thQ N/A) }\end{array}$ \\
\hline 7 & 0 & N/A & \\
\hline 8 & 0 & N/A & \\
\hline 9 & 6 & $\begin{array}{l}\text { Unprofessional conduct, and rude, } \\
\text { discourteous, disruptive, } \\
\text { disrespectful/6 from lawyers }\end{array}$ & $\begin{array}{l}6 \text { consultations } \\
\text { completed }\end{array}$ \\
\hline 10 & 0 & N/A & \\
\hline 11 & 3 & $\begin{array}{l}1 \text { unprofessional conduct, } 1 \text { abusive, } \\
1 \text { honesty, integrity, candor/1 from } \\
\text { public, } 2 \text { from lawyers }\end{array}$ & $\begin{array}{l}2 \text { complaint } \\
\text { dismissed }\end{array}$ \\
\hline 12 & 1 & Not indicated/1 from Lawyer & Not indicated \\
\hline 13 & $\begin{array}{l}1 \text { new } \\
3 \text { closed/1 } \\
\text { pending }\end{array}$ & $\begin{array}{l}\text { Rude, discourteous, disruptive, } \\
\text { disrespectful, Fair play, dilatory } \\
\text { tactics, disorganized or unprepared/2 } \\
\text { from lawyer, } 2 \text { Judge }\end{array}$ & $\begin{array}{l}3 \text { consultation } \\
\text { completed, } 1 \text { will be } \\
\text { disposed of } \\
\text { informally } \\
\text { July-September } 2014 \\
\text { (4thQ N/A) }\end{array}$ \\
\hline 14 & 0 & N/A & \\
\hline 15 & 2 & $\begin{array}{l}1 \text { unprofessional conduct, } 1 \text { honesty, } \\
\text { integrity, candor/ } 2 \text { from lawyer }\end{array}$ & $\begin{array}{l}1 \text { close, } 1 \text { pending } \\
\text { July-September } 2014 \\
(4 \text { thQ N/A) }\end{array}$ \\
\hline
\end{tabular}

${ }^{241}$ All information as part of reports given as Public Records request from Florida Bar obtained June 2015. In author's possession 


\begin{tabular}{|c|c|c|c|}
\hline 16 & 0 & N/A & $\begin{array}{l}\text { Admin order was } \\
\text { entered on } 12 / 15 / 14 \\
\text { creating panel. } \\
\text { Outreach was } \\
\text { established based on } \\
\text { criteria for the panel } \\
\text { and } 11 \text { members of } \\
\text { the local bar } \\
\text { submitted letters of } \\
\text { interested. Members } \\
\text { will be selected by } \\
\text { Chief Judge next } \\
\text { quarter }\end{array}$ \\
\hline 17 & 5 & $\begin{array}{l}1 \text { appearance impropriety, } 4 \\
\text { unprofessional conduct, } 3 \text { uncivil, } \\
\text { unruly, } 4 \text { rude, discourteous, } \\
\text { disruptive, disrespectful, } 2 \text { offensive } \\
\text { personality, } 2 \text { abusive, } 2 \text { honesty, } \\
\text { integrity, candor, } 2 \text { fair play, dilatory } \\
\text { tactics } 1 \text { used profanity/obscene } \\
\text { gestures, } 2 \text { bullying or badgering, } 1 \\
\text { illegality/ } 2 \text { by clients, } 1 \text { by public, } 1 \\
\text { from lawyer, } 1 \text { from judge }\end{array}$ & $\begin{array}{l}2 \text { consultations } \\
\text { completed, } 1 \text { referred } \\
\text { to the Florida Bar, } 2 \\
\text { under evaluation }\end{array}$ \\
\hline 18 & 1 & $\begin{array}{l}1 \text { failure to disclose conflicts/1 from } \\
\text { lawyer }\end{array}$ & 1 pending \\
\hline 19 & 2 & $\begin{array}{l}1 \text { rude, discourteous, disruptive, } \\
\text { disrespectful, } 1 \text { bullying or } \\
\text { badgering/ } 1 \text { from public, } 1 \text { from } \\
\text { lawyer }\end{array}$ & $\begin{array}{l}\text { letter to lawyer } \\
\text { advising dismissal } \\
\text { with reason, letter to } \\
\text { complainant advising } \\
\text { dismissal }\end{array}$ \\
\hline 20 & 2 & $\begin{array}{l}2 \text { unprofessional conduct } / 2 \text { from } \\
\text { members public }\end{array}$ & 2 no show \\
\hline
\end{tabular}

There are many important inferences to be made from this information. First, it is clear that although progress may be slow, the professionalism panels are being used. Although reports were not available for exactly the same time period for every circuit, looking at information available here, half of the circuits report receiving complaints. The reporting form to the Court gives a set of fixed choices to describe the subject matter of the complaint to the circuit, but it is clear that the majority of these matters involve what is within the purview of 
"unprofessionalism" from many definitions - including a blanket description of "unprofessional conduct" as well as attorneys being rude, disruptive, disrespectful, using obscene language, and other behavioral problems. While some of the reported complaints seem more in the bailiwick of clear ethical rule violations such as failure to disclose conflicts, most of these matters were not disposed of by reference to the Florida Bar, but rather by the LPP itself.

These panels are hearing complaints from a variety of sources—clients, the public, attorneys and judges. This diversity of origin means that information about these panels are reaching all of the constituencies who may wish to file complaints as is properly available to all. Therefore, it is simply possible that these panels simply need time to be able to operate at full speed.

In those circuits that have not heard complaints, there may be varying reasons, many of which can only be surmised. One circuit indicated that in the time period of reporting, it was first completing the process of establishing the panel. Others indicated that the panel was operating but simply did not receive any complaints. We cannot determine whether complaints are not reaching the panel, or there were no instances of purported professionalism violations. At the same time, we also can examine the Bar's formal complaint system intake data.

For the same time period as the majority of circuits reporting above (October-December, 2014) the Director of the Florida Bar's ACAP/Intake system provided a summary report to the Florida Supreme Court. During this time, it reported handling professionalism issues through the Bar's intake of the discipline system. ${ }^{242}$ According the report, there were 410 incidents involving appearance of impropriety, 316 of unprofessional conduct, 157 of rude, discourteous, disruptive, disrespectful behavior, 12 of offensive personality, 15 reported abusive, 70 involving bullying or badgering and 727 regarding an attorney being disorganized or unprepared. Each 
instance may not be a distinct complaint, as a one matter may involve more than one complaint. By contrast, ACAP also had 1,360 matters not involving a professionalism issue. It is clear that in addition to, or in cooperation with the Local Professionalism Panels, ACAP, as intake for the attorney discipline system, is also being engaged in another tool in the battle against unprofessional behavior.

\section{E. Nationwide}

Florida is not the only state to be struggling with the codification of professionalism rules. Many other states have enacted creeds, oaths, rules, and/or aspirational goals. Some states have aspirational goals, codes, or oaths, including Alabama, California, Delaware, Georgia, Hawaii, Idaho, Kentucky, Maryland, and Minnesota. ${ }^{243}$ Some Bars explicitly are taking the position that professionalism rules are separate from the Codes of professional conduct and marking a firm line between the aspirational and the enforceable legislation. Other states have mandated a set or a group of professionalism rules or creeds that are enfolded into their conduct rules, in effect making certain behaviors, including among them civility or professionalism binding and not merely aspirational, including Arizona, Arkansas, Michigan, New Mexico, South Carolina, Texas, and Utah. ${ }^{244}$ A full discussion of these diverse efforts is beyond the scope of this work, but highlights that the struggle is not unique to Florida.

\footnotetext{
${ }^{243}$ See Alabama State Bar, https://www.alabar.org (last visited July 30, 2015); Superior Court of California County of Nevada, http://nevadacountycourts.com (last visited July 30, 2015); Hawaii State Judiciary, http://www.courts.state.hi.us (last visited July 30, 2015); Kentucky Bar Association, http://www.kybar.org (last visited July 30, 2015); Maryland State Bar Association, http://www.msba.org (last visited July 30, 2015Minnesota State Bar Association, http://www.mnbar.org (last visited July 30, 2015).

${ }^{244}$ See State Bar of Arizona, http://www.azbar.org (last visited July 30, 2015); Justia, https://www.justia.com (last visited July 30, 2015); Michigan Courts, http://courts.mi.gov/Pages/default.aspx (last visited July 30, 2015); New Mexico Compilation Commission, http://www.nmcompcomm.us (last visited July 30, 2015); In Re Anonymous Member of S.C. Bar, 709 S.E.2d 633 (S.C. 2011); University of Houston Law Center, http://www.law.uh.edu (last visited July 30, 2015); Utah Courts, http://www.utcourts.gov (last visited July 30, 2015).
} 


\section{Lessons Learned and Possible Paths in Legal Education and the Profession}

The examination of codes, cases and committees in Florida leads to some important questions about enforcing professionalism. Why have a professionalism expectation different from the discipline system? Is the gap between them closing? Why do so many states go through the difficult process of "codifying" professionalism — making lists of behavior that are clearly not beneficial to the profession - then so clearly mark them as aspirational, explicitly saying that they cannot be used as the basis for discipline? Can professionalism really be defined? And assuming it can, what is the fear for disciplining for it?

One answer lies in the practical problem of enforcement. Assuming all professionalism complaints were brought into the formal discipline system, a fear is that "merely bad" behavior by attorneys would flood the discipline system, seizing it up and making it unworkable to handle problems that are deemed more serious - theft, felonies, and other breaches of fiscal trust.

Florida's system of professionalism panels seems a compromise on this point - that unprofessional behavior should not go unnoticed, but has a separate outlet to keep some matters out of the general discipline pipeline. The Supreme Court of Florida has indicated that it is not willing to allow attorneys to get away with being uncivil, with attacking other attorneys or judges - and to help attorneys quickly come to understand what is expected of them without flooding the system.

But clearly these panels cannot work alone. If a matter has come to a panel, it means someone has perceived a professionalism problem with an attorney. Any time we are retroactively trying to police behavior-particularly using a voluntarily process for the attorney involved in problem, we are dealing with a profession that is in trouble at its core. Therefore the next question is: What else can be done? 


\section{A. Increased Teaching Professionalism in Law Schools}

If organized bars are trying to educate already licensed lawyers as to professional behavior, an obvious companion to that is starting that education process earlier and more rigorously during the formal training of lawyers. For some law students, their only exposure to these problems will be a generally mandated class in "Professional Responsibility." While this is an excellent start, this course generally focuses on model rules-discipline based rules, and is often, anecdotally, taught to "the test" (the Multistate Professional Responsibility Exam) that new lawyers must pass to be admitted to practice. This kind of education is akin to the "floor"the lowest possible level of education on the subject we could give.

Some schools are doing more, however. Law schools in Florida have shared with the Florida Bar Professionalism Center their efforts to introduce and teach professionalism in law schools. Many schools introduce the concept of professionalism at orientation, including an oath of professionalism for students. ${ }^{245}$ In the Spring of 2014, all of the Florida law schools reported professionalism programs to the Center, including a variety of activities such as an Honor code recitation and pledge, a Professionalism enhancement program, sessions on Professionalism in the classroom, campus and community, a pathway to profession initiative, workshops, sessions integrated into classes, professionalism day, lunch and learns, professionalism awards, professionalism principles, orientation themes, and CLE program development within law schools. $^{246}$

The Thomas M. Cooley law school has an entire Center for professionalism, with its mission statement: "Supporting the law school's mission of preparing law students for professional practice, the Center for Ethics, Service, and Professionalism models and teaches

\footnotetext{
245 The Professional, A Publication of the Henry Latimer Center for Professionalism, Volume XI, No. 7, Spring 2014 at 10, wwww.flabar.org/professionalism.

246 Id. at $10-12$.
} 
ethics and professionalism, fosters and encourages service, and promotes commitment to our communities." 247 Other schools have had students take oaths of professionalism, whether their own creation, or that of the state bar in which they are located. ${ }^{248}$ The law schools oaths vary greatly_-some mirror state bar oaths regarding their behavior, such as civility and communication, while others try to focus on specific behavior of law students, such as checking email and staying in contact, and preparing adequately for class. ${ }^{249}$ Any focus on the promise to behave professionally is beneficial, as it plants the idea of an expectation as early as possible.

It is clear that law schools have made professionalism a topic of focus, but it is clear more could be done to focus not just on rules and regulations of academic codes, but on fostering lifelong positive attitudes toward the profession. Law schools should be thinking bigger when teaching and presenting professionalism to students, and we can look outside legal education for ideas. In 1997, a professor of literature founded the "Johns Hopkins Civility Project" later becoming the "Civility Institute" at the university to "work on assessing the significance of civility, manners, and politeness in contemporary society." ${ }^{250}$ Professor Forni, the author of the materials used in the program, without even defining civility, specifically makes a case for and sets forth basic rules of civility that could serve as an inspiration to law students and member of the Florida Bar in incorporating these ideas into everyday practice. ${ }^{251}$

\footnotetext{
${ }^{247}$ Western Michigan University Cooley Law School, http://www.cooley.edu/ethics/ (last visited June 21, 2015).

${ }^{248}$ See generally University of Dayton School of Law, https://www.udayton.edu/law/students/professionalism_oath.php (last visited June 21, 2015); Nova Southeastern University Shepard Broad College of Law, https://www.law.nova.edu (last visited June 21, 2015Washburn University School of Law, http://washburnlaw.edu/students/honorcode/oaths.html (last visited June 21, 2015). ${ }^{249}$ Washburn University School of Law, http://washburnlaw.edu/students/honorcode/oaths.html (last visited July 30, 2015).

${ }^{250}$ Sara L. Alpert \& William Reece Smith, Jr., Book Review Choosing Civility: The Twenty-five Rules of Considerate Conduct The Professional, A Publication of the Henry Latimer Center for Professionalism, Winter 2013 at 11, wwww.flabar.org/professionalism (reviewing P.M. Forni, Choosing Civility: The Twenty-five Rules of Considerate Conduct (2002)).

${ }^{251} \mathrm{Id}$.
} 
This call for the incorporation of professionalism into legal education is not unique or new. ${ }^{252}$ In 2014, The New York State Judicial Institute on Professionalism in the Law was working jointly with the New York State Bar Association Committee on Legal Education and Admission to the Bar, revisiting work nearly a decade old, to examine the future of legal education, including the inculcation of professional values in law school. ${ }^{253}$ It defined professional behaviors as including: lawyer independence, ethical behavior, self-renewal, competence, excellence, responsibility, historical continuity and tradition of the profession, breadth and diversity of the profession, respect for client adversary and the court, and societal context of the law. ${ }^{254}$ These core values need to be more heartily stressed and explored by law students.

One scholar has advocated for using an "Assessment of Student Professionalism” model from the University Of California San Francisco School Of Medicine, where students are subject to an evaluation of professionalism skills in addition to their more traditional assessments. ${ }^{255}$ It has been suggested that this model could be coopted to create a similar assessment process for law students, to better prepare students for the practice of law, as advocated by the MacCrate report and others. ${ }^{256}$ With the ABA shining a bright spotlight on learning outcomes in legal education, it seems an ideal time to turn the focus on adding such nontraditional ones as professionalism into the learning outcome mix and developing new paradigms to assess them. We can look to such other disciplines to see how they have handled this within their curriculum.

Other professional schools have in fact more directly enforced professionalism in students. In 2012, the US Court of Appeals for the Fourth Circuit affirmed a summary judgement

\footnotetext{
252 Denise Platfoot Lacey, Embedding Professionalism into Legal Education, 18 J.L. Bus. \& Ethics 41, 48 (2012).

${ }^{253}$ Letter from New York State Judicial Institute of Professionalism in the Law (Feb. 12, 2014) in author's possession.

${ }^{254} I d$.

${ }^{255}$ Lacey supra note 252 at 48.

${ }^{256} I d$. at 53.
} 
in favor of Wake Forest University Health Sciences dismissing a student for unprofessional behavior. ${ }^{257}$ One of the fundamental education goals of the school's curriculum was that students establish professional attitudes and behavior, which to satisfy such goal, students much demonstrate their ability to work with "other health care professionals, adherence to highest standards of integrity, ability to admit mistakes and lack of knowledge and other identified aspects of professional behavior" before they graduate. ${ }^{258}$ The student in question had difficulties with professionalism immediately in the program and through the first two years, including reports of very abusive behavior and other actions, which he later attributed to side effects of his undisclosed ADHD medication. ${ }^{259}$ While it is documented that he struggled in other areas such as medical knowledge, the assertion in this case was that his largest obstacle to continuing his education was his frequent lapses in professionalism, including being resistant to feedback, lack of interpersonal skills, and absences without permission. Ultimately the school recommended dismissal based on a pattern of unprofessional behavior. ${ }^{260}$ The court here found that professionalism was an essential requirement of the program and that the student ultimately, with or without reasonable accommodations for his medication, would not be qualified for the program. ${ }^{261}$

In 2015, The United States Court of Appeals for the Sixth Circuit determined that a medical student's lack of professionalism supported Case University School of Medicine's decision not to award his diploma. ${ }^{262}$ The medical school curriculum explicitly described professionalism by students in four ways: first, consistently demonstrating ethical, honest, responsible and reliable behavior, second, identifying challenges to professionalism and

${ }^{257}$ Halpern v. Wake Forest University Health Sciences, 669 F.3d 454 (2012).

${ }^{258} I d$.

${ }^{259} I d$.

${ }^{260} \mathrm{Id}$.

${ }^{261} \mathrm{Id}$.

${ }^{262}$ Al Dabagh v. Case Western Reserve University, 23 F.Supp.3d 865 (2014). 
developing a strategy to maintain the professional behaviors when adherence to professional standards is threated in the clinical and or research settings, third, engaging in respectful dialogue with peers, faculty and patients to enhance learning and resolve differences, and fourth, to recognize personal limitations and biases and find ways to overcome them. ${ }^{263}$ Students cannot receive a degree without committee approval finding they meet these learning outcomes of professionalism. ${ }^{264}$ The student in question had a history of academic excellence but additionally a history of professionalism issues including consistently lateness, accusations of improper sexual behavior with two female students, being kicked out of hospital rooms by families, complaints by nurses and hospital staff about his demeanor and ultimately a DUI conviction. ${ }^{265}$ Rather than withdrawing as requested, he sued in Federal District, who agreed with him and ordered the university to award his degree. ${ }^{266}$ Upon appeal, the circuit court held that a court must show great respect for the faculty's professional judgment and may not override that judgment unless it is such a substantial departure from accepted academic norms in a way that that committee did not exercise professional judgment correctly. ${ }^{267}$ It was found that the professionalism outcomes were adequately described and implemented in this program, and as such his degree was withheld. ${ }^{268}$

The concern in the way law schools often handle teaching professionalism mirrors the struggle going on in state Bars nationwide—-should professionalism be aspirational in the law school setting or should it be part of an enforced code? Should it be taught informally through class discussions and enrichment sessions, or should it be embedded specifically in the curriculum and assessed accordingly? Law schools cannot look to the Bar for answers on how to

\footnotetext{
${ }^{263} I d$.

${ }^{264} I d$.

${ }^{265} I d$.

${ }^{266} I d$.

${ }^{267} \mathrm{Id}$.

${ }^{268} I d$.
} 
train future lawyers. They must lead the charge to change the tide in the turning out of new lawyers.

\section{B. Other Efforts in Professionalism Education}

Voluntary Bar groups have started to recognize the value of reaching not just lawyersbut future lawyers, in trying to turn the profession around by its roots. Many statewide voluntary bars plan events for law students "aimed at educating attendees about the wonderful benefits of embracing professionalism"269 This modeling of good behavior, and partnering with law schools can only enhance other efforts, but must be paired with programs from within legal education as well.

The Florida Bar's Professionalism Center works tirelessly to promote professionalism among attorneys and educate and share information about it. In addition to publishing original and collected articles about various happenings, collecting and disseminating professionalism reports from both the circuits around the state and the law schools in an effort to help spread the word about them, the center encourages all manner of education and leadership in this area. ${ }^{270}$ Some examples of activities in the past year throughout the state have included CLE cruises, conferences, bench/bar breakfasts, seminars, awards, outreach, mentoring, luncheons, social networking events and other programs aimed at getting lawyers to learn and talk about professionalism in the practice of law. ${ }^{271}$ The long term goals of these programs is to hopefully make the debate about whether to enforce professionalism through discipline moot. It is clear they have a long way to go, but their efforts are extremely admirable.

\footnotetext{
${ }^{269}$ Caroline Johnson Levine, Professionalism for Law Students, The Professional, A Publication of the Henry Latimer Center for Professionalism, Volume XI, No. 6, Winter 2013 at 8, wwww.flabar.org/professionalism.

${ }^{270}$ The Professional, A Publication of the Henry Latimer Center for Professionalism, Volume XI, No 7, Spring 2014 wwww.flabar.org/professionalism.

${ }^{271}$ Id. at 5-8.
} 
These efforts are not limited to local or state bars. It is clear a national conversation is ongoing throughout the legal community. In a recent issue of the Professional, by the Florida Bar, more than a dozen resources are listed to learn about professionalism through the ABA, various Law Reviews, Bar Associations and other publications. ${ }^{272}$ For several years, the national American Board of Trial Advocates (ABOTA) has presented an educational program called "Civility Matters" to bar association groups and law schools. One of the core missions of ABOTA, made up equally of civil defense and plaintiffs' trial counsel and with nearly 7,000 members in all 50 states, is the promotion of professionalism and civility. A committee in the national organization has encouraged states to amend their oaths of admission to require civility in all dealings. ${ }^{273}$

The American Civil Trial Bar Roundtable published a white paper to "suggest effective strategies for strengthening the professionalism of lawyers, building on the extensive initiatives of courses, bars, legal organizations and law schools" $" 274$ One of its premises, that the unprofessional conduct of lawyers undermines the civil justice system, is based on previous work in this area. ${ }^{275}$ It notes that because of lawyers' central role in assuring that the principles of law are properly applied, unprofessional conduct results in delays, costs, and can result in loss of public confidence in the civil justice system. ${ }^{276}$ It is not, therefore, merely a problem of "bad behavior."

The White Paper goes on to detail current professionalism initiatives. First it discusses various commissions by state courts, and then by state bars on various levels. ${ }^{277}$ Additionally, it reviews bar professionalism codes, oaths, mandatory CLE programs mentoring programs, law

\footnotetext{
${ }^{272}$ Id. at 14

273 Pudlow, supra note 149.

274 Supra note 4 at 2.

275 Id. at 3.

276 Id. at 5.

${ }^{277}$ Id. at 6.
} 
schools' increasing contributions, as well as those of national legal organizations and others. ${ }^{278}$ It is clearly a work advocating for professionalism to be raised in importance nationwide by attorneys while offering ideas and encouragement for all.

\section{Conclusions}

Professionalism has an identity crisis in the legal profession. While many extol on its importance to the central core of our being as attorneys, others give mere "behavior" problems second class status in considering the regulation of our profession. Some claim to define the parameters of professionalism, others claim it is by definition elusive and vague. There are real challenges to changing the culture of attorneys, many whom were raised on the idea that attorneys win at any cost, including their reputations, civility and humanity.

The "what" and "how" of making lawyers play nice has no clear answer. Closing the gap between aspirations and expectations is a good start. But one basic notion is clear-can this profession continue to grow and flourish without attorneys exhibiting professional behavior or the profession having a clear path to improve it? The answer is no-and that all those who seek to uphold our profession, its service ideals, and commitment to justice need to continue to cooperate toward a solution.

${ }^{278} I d$. at 7. 